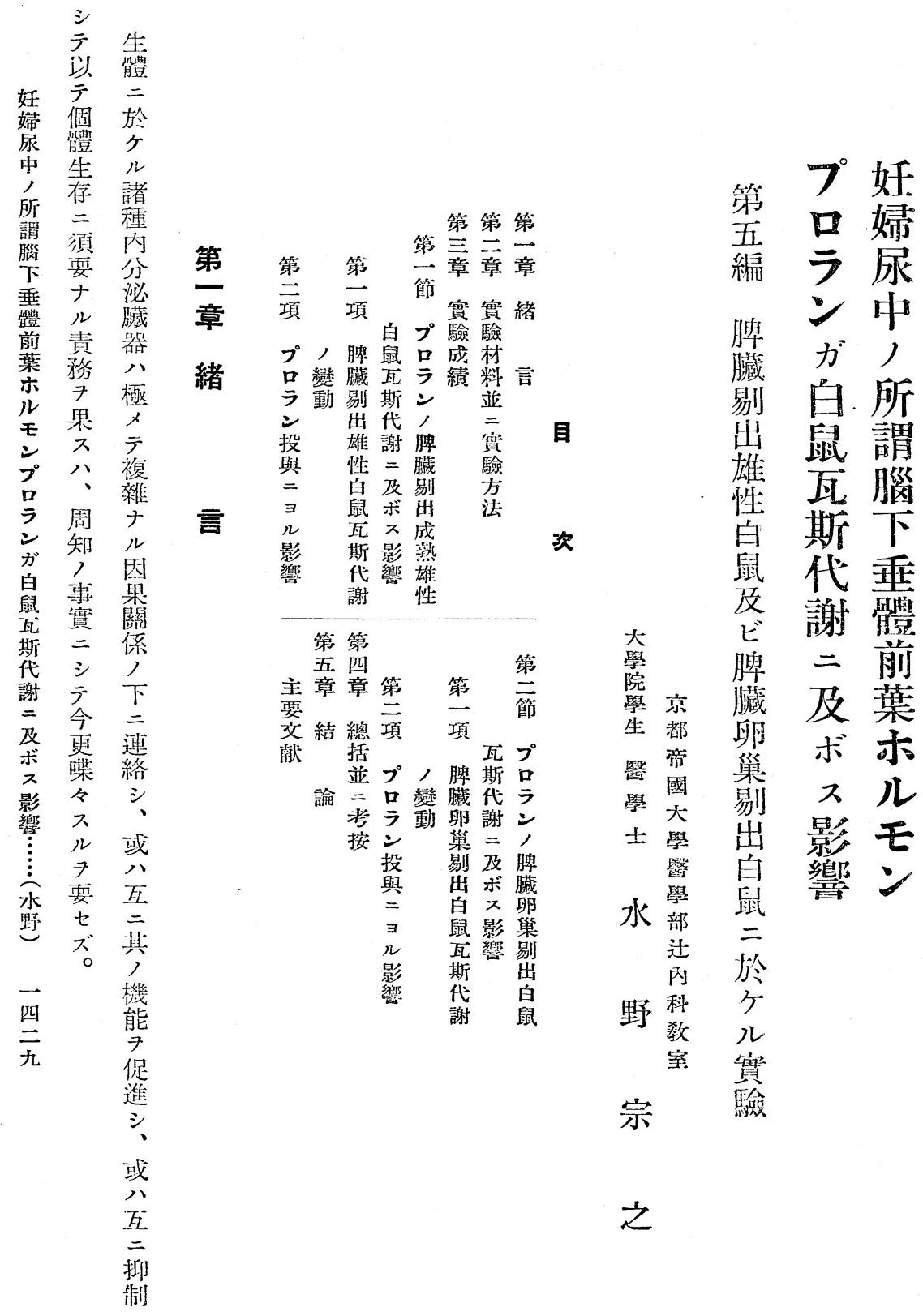




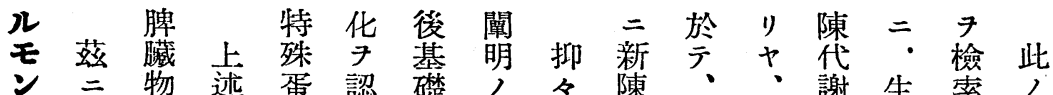

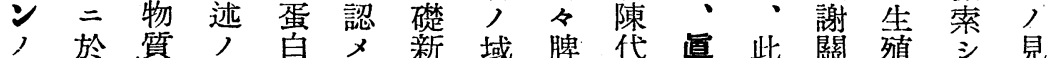

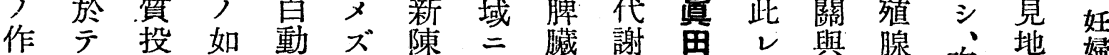
用余與 ク力ト代達ガ

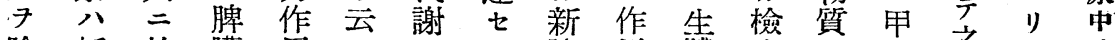

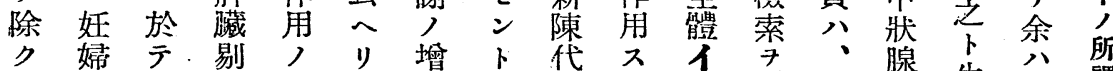

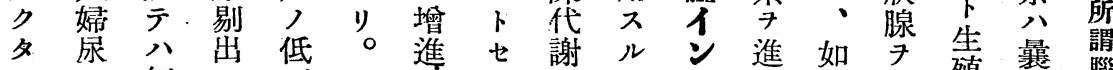
タ 尿 卵得 モ

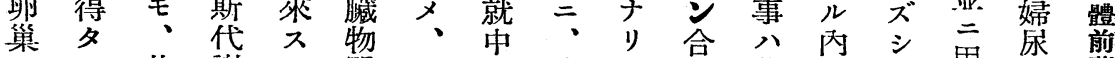

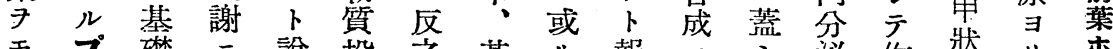
モプ 礎二說投之 基 ル 報二シ 泌作狀り 棉 併口新及ク與礎種 ズ 於與腺角腺得ル

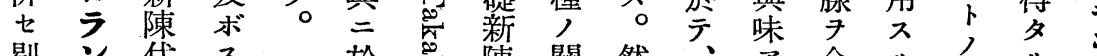

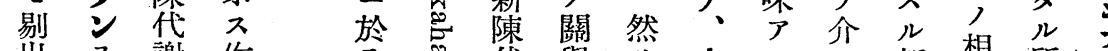

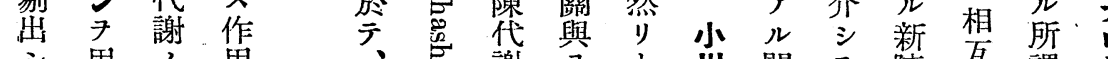

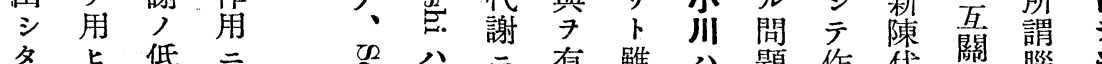

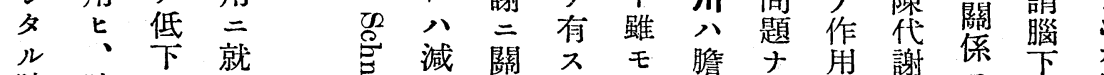

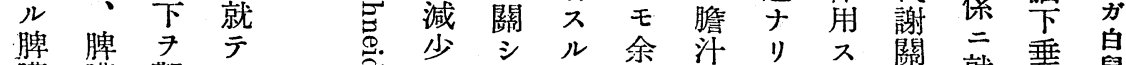
藏 臟 敬 ハ 卯剔ル㧘 鼠出 モ 續

剔雄ノ種 出性、令 白白如 鼠鼠 シ 斯斯、 代 代其 謝謝歸 及二 ボプ ル

ス 口所

プ 六

ラ.中必

$y=$

含

影有

響 サ

无 ラ

檢性弪

索 性

シ 盛

併禾

㐏

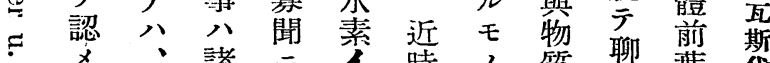

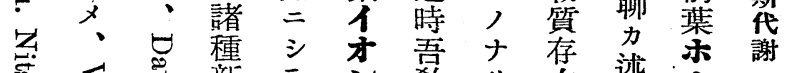

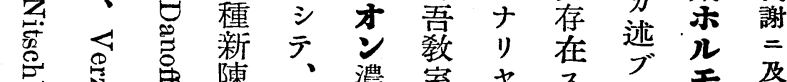

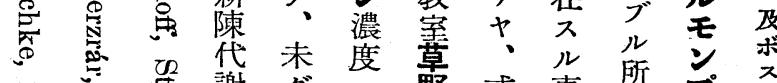

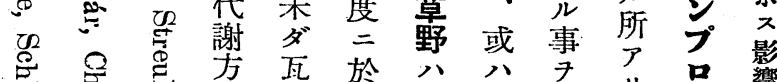

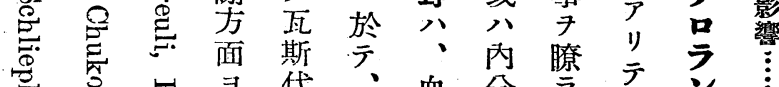
卜變出ク○的二ナ新外響 


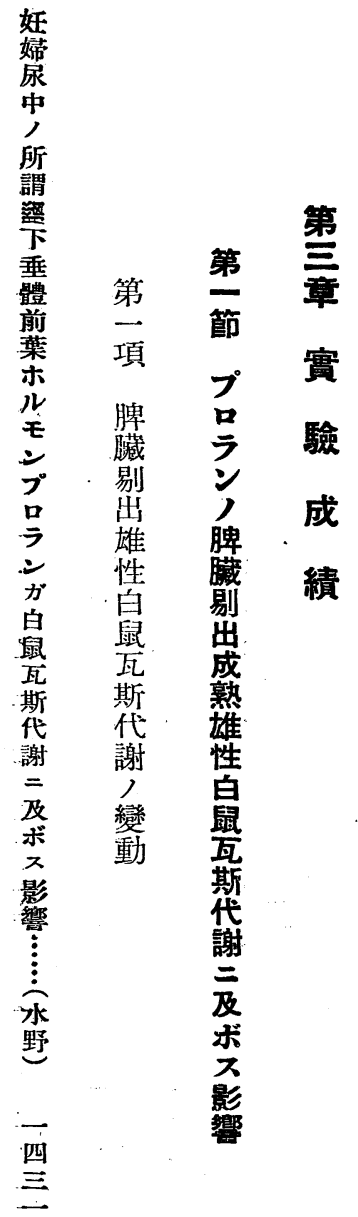

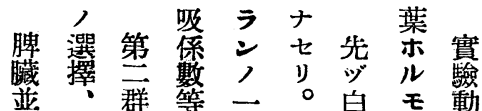

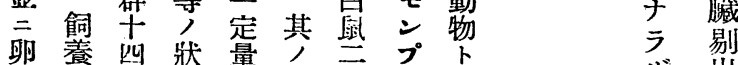

巢竟元態显內干品

剔法每交六ラテ

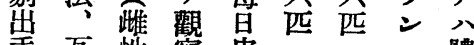

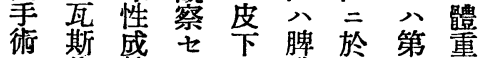

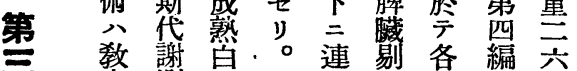

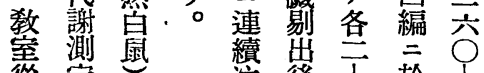

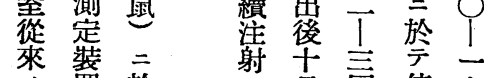

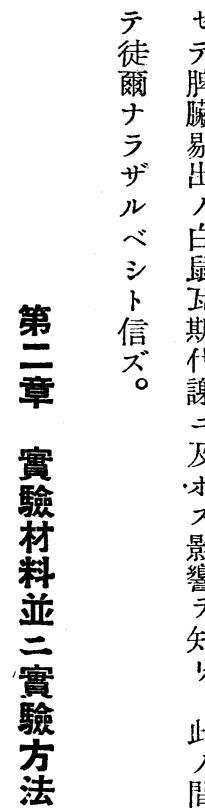

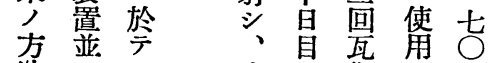

法立、注星斯志宜

從法脾翌吾謝毛健

人贜音豆 $\Rightarrow$, 常

》。余留白自檢卜雄 勧当繁全性

暨吾

鋥時間畜後製第

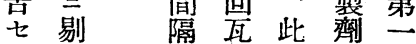

几出 $\quad \exists$ 斯 $2=$ 群

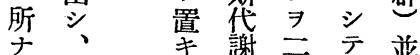

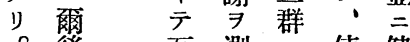

後瓦測公使健

斯定分角常凟

記氐艺量成不

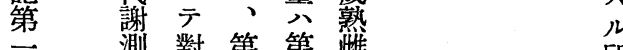

群，刻對第第踓所

名臂 編自

夫施ナ吉鼠

$=$ 行 シ 元記第

了

淮三䇝雄志臂

瓦市六性 所

斯六元感從使

本

踰

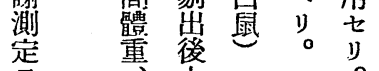

企

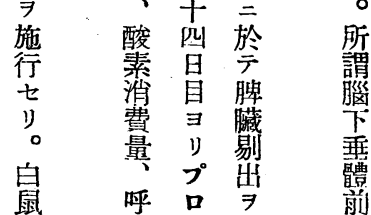


籍一表 第一群

\begin{tabular}{|c|c|c|c|c|c|c|c|}
\hline \multirow[b]{2}{*}{ 檢查日附 } & \multirow{2}{*}{$\begin{array}{ll}\text { 絕 } & \text { 食 } \\
& \text { 時 間 }\end{array}$} & \multirow[b]{2}{*}{ 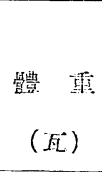 } & \multicolumn{3}{|c|}{$\begin{array}{c}\text { 隐 斯 代 謝 } \\
\text { 得㻉 } 0^{\circ} \mathrm{U} 760 \mathrm{~mm} \mathrm{Hg}\end{array}$} & \multirow{2}{*}{$\begin{array}{l}\text { 呼 吸 } \\
\text { 係 數 }\end{array}$} & \multirow[b]{2}{*}{$\begin{array}{c}\text { 酸素 } \\
\text { 消費量 } \\
\text { 增减絫 } \\
(\%)\end{array}$} \\
\hline & & & 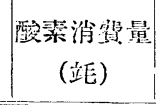 & 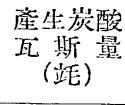 & 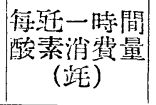 & & \\
\hline \multicolumn{8}{|c|}{ 白 } \\
\hline $18 / \square$ & 24 & 170 & 213.24 & 162.00 & 1254.37 & 0.759 & \\
\hline $21 / \|$ & 24 & 172 & 231.14 & 170.00 & 1343.86 & 0.752 & \\
\hline 平 均 & & 171 & 222.19 & 166.00 & 1299.12 & 0.756 & \\
\hline $23 / I I$ & \multicolumn{7}{|c|}{ 脾 } \\
\hline $5 /$ III & 24 & 140 & 200.29 & 154.00 & 1430.73 & 0.768 & +10.1 \\
\hline $10 / \mathbb{I I}$ & 24 & 149 & 215.46 & 160.00 & 1446.05 & 0.742 & +11.3 \\
\hline $15 / "$ & 24 & 172 & 238.12 & 184.00 & 1384.44 & 0.772 & +6.5 \\
\hline $20 / 11$ & 24 & 182 & 247.9. & 190.00 & 1362.36 & 0.766 & +4.8 \\
\hline $25 / 11$ & 24 & 183 & 256.58 & 188.00 & 1401.01 & 0.732 & +7.8 \\
\hline $30 / \|$ & 24 & 184 & 265.22 & 200.00 & 1441.46 & 0.753 & +10.9 \\
\hline $4 / \mathrm{IV}$ & 24 & 193 & 277.13 & 210.00 & 1435.93 & 0.757 & +-10.5 \\
\hline \multicolumn{8}{|c|}{ 白 } \\
\hline $22 / \mathbb{I}$ & 24 & 196 & 240.32 & 180.00 & 1226.13 & 0.748 & \\
\hline $25 / "$ & 24 & 184 & 237.33 & 172.00 & 1289.85 & 0.727 & \\
\hline 平 均 & & 190 & 238.83 & 176.00 & 1257.99 & 0.736 & \\
\hline $24 / I I$ & \multicolumn{7}{|c|}{ 脾 臟 剔 出 } \\
\hline $6 / \mathbb{I I}$ & 24 & 175 & 242.37 & 182.00 & 1363.35 & 0.750 & +8.8 \\
\hline 11/III & 24 & 157 & 207.42 & 156.00 & 1321.16 & 0.745 & +5.0 \\
\hline $16 / 11$ & 24 & 173 & 225.96 & 170.00 & 1306.15 & 0.752 & +3.8 \\
\hline $21 / \prime \prime$ & 24 & 190 & 276.83 & 208.00 & 1457.04 & 0.751 & +15.8 \\
\hline $26 / \|$ & 24 & 189 & 261.60 & 200.00 & 1384.12 & 0.764 & +10.0 \\
\hline $31 / /$ & 24 & 197 & 266.74 & 202.00 & 1354.01 & 0.757 & +7.6 \\
\hline $5 / I V$ & 24 & 201 & 264.68 & 200.00 & 1316.82 & 0.755 & +4.6 \\
\hline
\end{tabular}




\begin{tabular}{|c|c|c|c|c|c|c|c|}
\hline \multirow[b]{2}{*}{ 臉查日附 } & \multirow{2}{*}{$\begin{array}{l}\text { 絕 食 } \\
\text { 時 間 }\end{array}$} & \multirow[b]{2}{*}{$\begin{array}{l}\text { 體 重 } \\
\text { (瓦) }\end{array}$} & \multicolumn{3}{|c|}{$\begin{array}{c}\text { 瓦斯 代 謝 } \\
\text { 每時 } 0^{\circ} \mathrm{C} 760 \mathrm{~mm} \mathrm{Hg}\end{array}$} & \multirow{2}{*}{$\begin{array}{l}\text { 呼 吸 } \\
\text { 俰 数 }\end{array}$} & \multirow{2}{*}{$\begin{array}{l}\text { 酸 素 } \\
\text { 洞費 } \\
\text { 增減率 } \\
(\%)\end{array}$} \\
\hline & & & $\mid \begin{array}{c}\text { 剽素消費量 } \\
\text { (靖) }\end{array}$ & $\begin{array}{l}\text { 產生炭酸 } \\
\text { 量 } \\
\text { (斯) }\end{array}$ & $\begin{array}{c}\text { 等酒一時間 } \\
\text { 酸素消䨘量 } \\
\text { (站) }\end{array}$ & & \\
\hline \multicolumn{8}{|c|}{ 白 } \\
\hline $20 / \pi$ & 24 & 190 & 244.58 & 180.00 & 1287.27 & 0.736 & \\
\hline $23 / " /$ & 24 & 180 & 248.76 & 186.00 & 1382.00 & 0.747 & \\
\hline 平 均 & & 185 & 246.67 & 183.00 & 1334.64 & 0.742 & \\
\hline $25 / \mathbb{I}$ & \multicolumn{7}{|c|}{ 脾 閨 剔 出 } \\
\hline 7 / 任 & 24 & 182 & 264.24 & 196.00 & 1451.90 & 0.741 & +8.7 \\
\hline $12 /$ III & 24 & 188 & 278.74 & 210.00 & 1482.68 & 0.753 & +11.0 \\
\hline $17 / / 1$ & 24 & 191 & 269.62 & 194.00 & 1411.66 & 0.719 & +5.7 \\
\hline $22 / "$ & 24 & 182 & 244.74 & 186.00 & 1344.73 & 0.759 & +0.7 \\
\hline $27 j " 1$ & 24 & 178 & 246.14 & 184.00 & 1382.83 & 0.747 & +3.6 \\
\hline $1 / I V$ & 24 & 181 & 261.76 & 196.00 & 1446.19 & 0.748 & +8.3 \\
\hline $6 / 1 /$ & 24 & 186 & 264.37 & 200.00 & 1421.38 & $0.7 \tilde{6}$ & +6.4 \\
\hline \multicolumn{8}{|c|}{ 白 } \\
\hline 11/III & 24 & 229 & 275.10 & 212.00 & 1201.34 & 0.770 & \\
\hline $13 / 1 /$ & 24 & 217 & 254.43 & 204.00 & 1172.49 & 0.801 & \\
\hline 平 均 & & 223 & 264.77 & 208.00 & 1186.92 & 0.786 & \\
\hline $12 /$ III & \multicolumn{7}{|c|}{ 脾 } \\
\hline $22 / \|$ & 24 & 216 & 260.66 & 212.00 & 1206.77 & 0.814 & -1.6 \\
\hline $27 /$ II & 24 & 222 & 271.66 & 212.00 & 1223.73 & 0.780 & $\div 3.1$ \\
\hline $1 /$ IV & 24 & 223 & 268.85 & 212.00 & 1205.62 & 0.787 & +1.5 \\
\hline $6 / "$ & 24 & 227 & 243.45 & 194.00 & 1072.49 & 0.796 & -9.6 \\
\hline $11 / "$ & 24 & 228 & 268.97 & 208.00 & 1179.73 & 0.773 & -0.6 \\
\hline $16 / / /$ & 24 & 230 & 306.04 & 232.00 & 1330.63 & 0.758 & $\div 12.1$ \\
\hline $21 / " \prime$ & 24 & 230 & 256.98 & 196.00 & 1117.30 & 0.762 & -5.8 \\
\hline
\end{tabular}




\begin{tabular}{|c|c|c|c|c|c|c|c|}
\hline \multirow[b]{2}{*}{ 檢查日附 } & \multirow{2}{*}{$\begin{array}{l}\text { 絕 食 } \\
\text { 時 間 }\end{array}$} & \multirow[b]{2}{*}{$\begin{array}{c}\text { 體 重 } \\
\text { (瓦) }\end{array}$} & \multicolumn{3}{|c|}{$\begin{array}{c}\text { 逦 斯 代 謝 } \\
\text { 每時 } 0^{\circ} \mathrm{C} 760 \mathrm{mmH}\end{array}$} & \multirow{2}{*}{$\begin{array}{l}\text { 呼 吸 } \\
\text { 倸 數 }\end{array}$} & \multirow{2}{*}{ 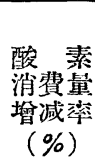 } \\
\hline & & & $\left|\begin{array}{c}\text { 酸素消䩀量 } \\
\text { (站) }\end{array}\right|$ & $\begin{array}{l}\text { 这生炭酸 } \\
\text { 瓦斯 量 } \\
\text { (犝) }\end{array}$ & 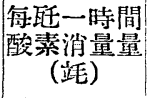 & & \\
\hline \multicolumn{8}{|c|}{ 白 } \\
\hline $10 /$ III & 24 & 195 & 255.89 & 200.00 & 1312.28 & 0.781 & \\
\hline $14 / / /$ & 24 & 190 & 261.60 & 196.00 & 1376.85 & 0.749 & \\
\hline 本 均 & & 193 & 258.75 & 198.00 & 1344.57 & 0.765 & \\
\hline $14 / \mathbb{I I}$ & \multicolumn{7}{|c|}{ 脾 臟 剔 出 } \\
\hline 24/ II & 24 & 185 & 231.71 & 180.00 & 1252.52 & 0.776 & -6.8 \\
\hline $29 / \| 1$ & 24 & 190 & 235.03 & 184.00 & 1237.02 & 0.782 & -7.9 \\
\hline $3 / I V$ & 24 & 190 & 263.20 & 188.00 & 1385.30 & 0.714 & +3.0 \\
\hline $8 / 11$ & 24 & 192 & 240.13 & 190.00 & 1250.65 & 0.791 & -6.9 \\
\hline $13 / / 8$ & 24 & 195 & 234.27 & 180.00 & 1201.41 & 0.768 & -10.6 \\
\hline $18 / \|$ & 24 & 190 & 244.14 & 172.00 & 1284.97 & 0.704 & -4.4 \\
\hline $23 / 11$ & 24 & 190 & 238.65 & 176.00 & 1256.07 & 0.737 & -6.5 \\
\hline \multicolumn{8}{|c|}{ 自 } \\
\hline $12 / \mathrm{II}$ & 24 & 188 & 222.80 & 172.00 & $3] 85.61$ & $0.7 \%$ & \\
\hline $14 \%$ & 24 & 172 & 227.90 & 172.00 & 1825.01 & 0.754 & \\
\hline 可 地 & & 180 & 225.40 & 172.60 & 1255.81 & 0.769 & \\
\hline $1.1 /$ III & \multicolumn{7}{|c|}{ 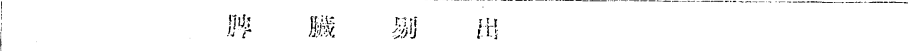 } \\
\hline $24 / 11$ & 24 & 171 & 216.65 & 164.00 & 1266.99 & 0.756 & +0.9 \\
\hline $29 / 111$ & 24 & 175 & 216.93 & 162.00 & $1289.8 \mathrm{~A}$ & 0.716 & -1.2 \\
\hline $3 / \mathrm{IV}$ & 24 & 182 & 247.74 & 186.00 & 1.61 .25 & 0.750 & +8.4 \\
\hline $8 / 11$ & 24 & 184 & 227.60 & $176: 00$ & 1236.98 & 0.773 & -1.4 \\
\hline $13 / / 1$ & 24 & 186 & 257.14 & 192.00 & 1382.47 & 0.746 & +9.1 \\
\hline $18 / " 1$ & 24 & 187 & 223.86 & 160.00 & $119 . .11$ & 0.714 & -4.8 \\
\hline $23 / 11$ & 24 & 185 & 222.94 & 164.00 & 1205.09 & 0.735 & -4.0 \\
\hline
\end{tabular}




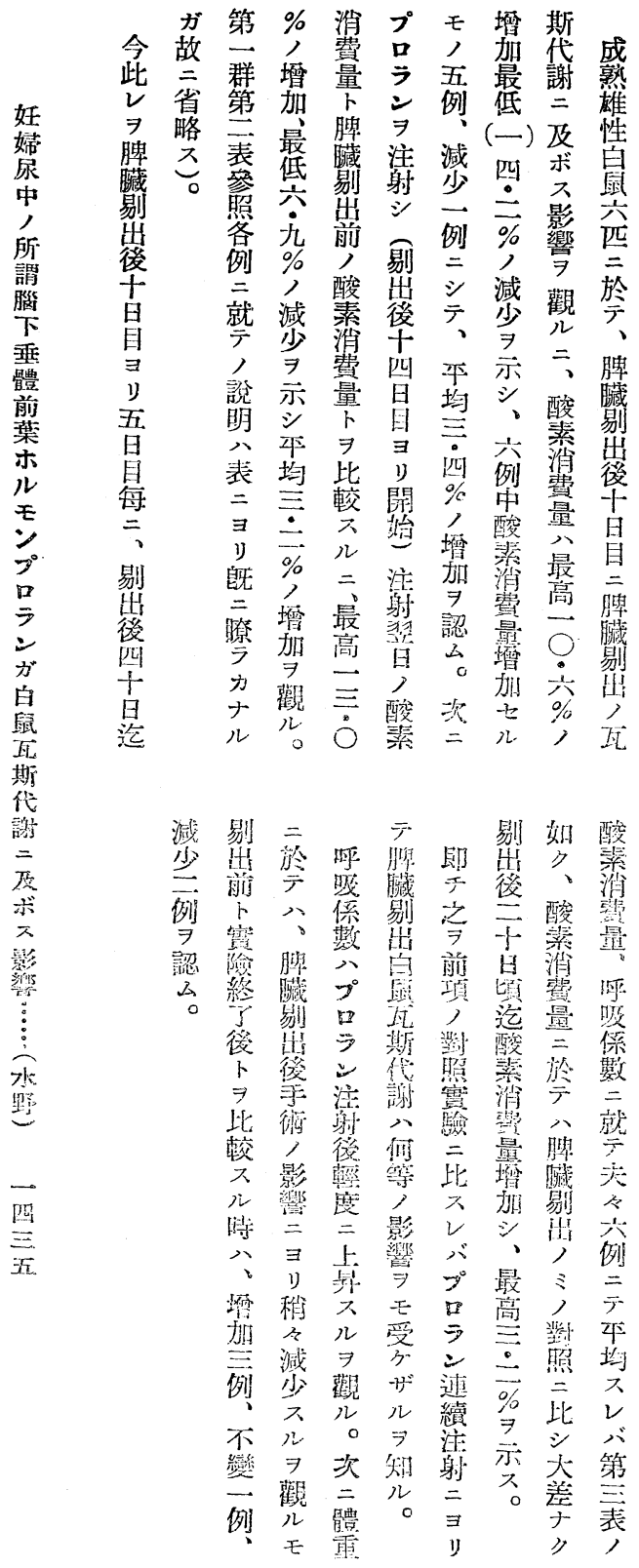

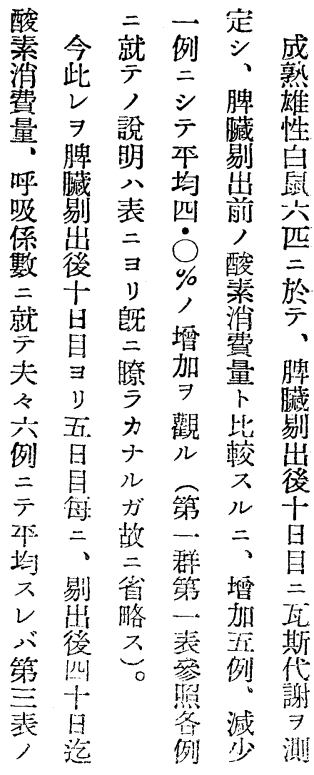

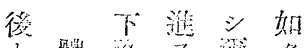

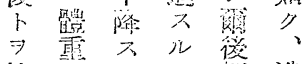

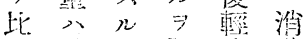

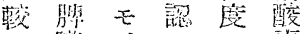

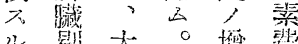

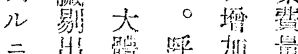
$=$ 们 腈

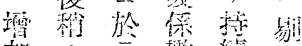

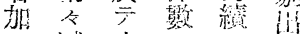

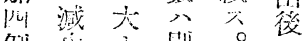
例方 广 剔明

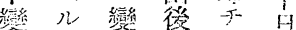
元 7 列

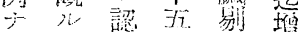
リ * 、元昭 ○勋。利 $\exists$ 最 䄀合少亯

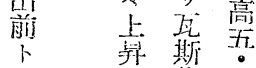

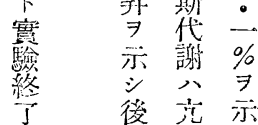


第二表 第一群

\begin{tabular}{|c|c|c|c|c|c|c|c|}
\hline \multirow[b]{2}{*}{ 檢查日附 } & \multirow{2}{*}{$\begin{array}{l}\text { 絕 食 } \\
\text { 時 間 }\end{array}$} & \multirow[b]{2}{*}{$\begin{array}{c}\text { 體 重 } \\
\text { (瓦) }\end{array}$} & \multicolumn{3}{|c|}{$\begin{array}{c}\text { 氐 斯 代 謝 } \\
\text { 每時 } 0^{\circ} \mathrm{C} 760 \mathrm{~mm} \mathrm{Hg}\end{array}$} & \multirow{2}{*}{$\begin{array}{l}\text { 呼 吸 } \\
\text { 係 數 }\end{array}$} & \multirow{2}{*}{$\begin{array}{c}\text { 酸 素 } \\
\text { 消費量 } \\
\text { 增减率 } \\
(\%) \\
(\%)\end{array}$} \\
\hline & & & $\mid \begin{array}{c}\text { 消費酸素量 } \\
\text { (靖) }\end{array}$ & $\begin{array}{l}\text { 宸生炭酸 } \\
\text { 瓦斯 量 } \\
\text { (距) }\end{array}$ & 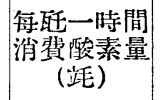 & & \\
\hline \multicolumn{8}{|c|}{ 白 } \\
\hline $17 / \mathbb{I}$ & 24 & 178 & 236.47 & 172.00 & 1328.49 & 0.727 & \\
\hline $20 / 11$ & 24 & 177 & 234.31 & 168.00 & 1323.82 & 0.716 & \\
\hline 平 此 & & 178 & 235.39 & 170.00 & 1326.16 & 0.722 & \\
\hline $22 / \mathbb{I}$ & \multicolumn{7}{|c|}{ 脾 臟 剔 出 } \\
\hline $4 /$ 倓 & 24 & 177 & 259.68 & 196.00 & 1467.15 & 0.754 & +10.6 \\
\hline $8 /$ III & \multicolumn{7}{|c|}{ プロラン A.B. 注射開始 } \\
\hline $9 / \|$ & 24 & 174 & 260.82 & 200.00 & 1499.00 & 0.766 & +13.0 \\
\hline $14 / "$ & 24 & 180 & 259.16 & 192.00 & 1439.81 & 0.740 & +8.5 \\
\hline $19 / / /$ & 24 & 170 & 252.48 & 192.00 & 1485.20 & 0.760 & +11.9 \\
\hline $24 / 1 /$ & 24 & 174 & 225.14 & 168.00 & 1293.93 & 0.746 & -2.4 \\
\hline $29 / 11$ & 24 & 180 & 269.42 & 206.00 & 1496.80 & 0.764 & +12.8 \\
\hline $3 / I V$ & 24 & 182 & 250.45 & 188.00 & 1376.09 & 0.750 & +3.7 \\
\hline \multicolumn{8}{|c|}{ 白 } \\
\hline $18 /$ II & 24 & 248 & 358.75 & 266.00 & 1446.73 & 0.741 & \\
\hline $23 / " /$ & 24 & 250 & 352.82 & 266.00 & 1411.30 & 0.753 & \\
\hline 本 均 & & 249 & 355.79 & 266.00 & 1429.02 & 0.747 & \\
\hline $22 / \mathbb{I}$ & \multicolumn{7}{|c|}{ 脾 臟 剔 出 } \\
\hline $5 /$ III & 24 & 222 & 330.50 & 236.00 & 1488.74 & 0.714 & +4.1 \\
\hline $9 / \mathbb{I I}$ & \multicolumn{7}{|c|}{ プロラン A. B. 注射開炲 } \\
\hline $10 / 1 /$ & 24 & 227 & 331.34 & 250.00 & 1459.65 & 0.754 & +2.1 \\
\hline $15 / / 1$ & 24 & 240 & 355.85 & 270.00 & 1482.73 & 0.758 & +3.7 \\
\hline $20 / " 1$ & 24 & 240 & 321.57 & 250.00 & 1339.91 & 0.777 & -6.2 \\
\hline $25 / 1 /$ & 24 & 240 & 361.68 & 264.00 & 3.507 .03 & 0.729 & +5.4 \\
\hline $30 / "$ & 24 & 248 & 358.77 & 254.00 & 1446.68 & 0.707 & +1.2 \\
\hline $4 / 1 \mathrm{~V}$ & 24 & 263 & 385.26 & 278.00 & 1464.90 & 0.721 & +2.5 \\
\hline
\end{tabular}




\begin{tabular}{|c|c|c|c|c|c|c|c|}
\hline \multirow[b]{2}{*}{ 檢桎日附 } & \multirow{2}{*}{$\begin{array}{ll}\text { 絕 } & \text { 食 } \\
\text { 時 } & \text { 間 }\end{array}$} & \multirow[b]{2}{*}{ 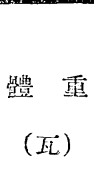 } & \multicolumn{3}{|c|}{$\begin{array}{c}\text { 丽 斯 代 謝 } \\
\text { 等㭙 } 0^{\circ} \mathrm{C} 760 \mathrm{~mm} \mathrm{Hg}\end{array}$} & \multirow{2}{*}{$\begin{array}{l}\text { 呼 吸 } \\
\text { 保 数 }\end{array}$} & \multirow{2}{*}{ 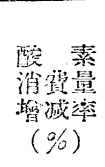 } \\
\hline & & & $\begin{array}{c}\text { 酸素消貿量 } \\
(\text { 此) }\end{array}$ & $\begin{array}{c}\text { 產生荻酸 } \\
\text { 瓦斯暴 } \\
\text { (站) }\end{array}$ & 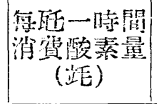 & & \\
\hline \multicolumn{8}{|c|}{ 白 } \\
\hline $17 /$ II & 24 & 226 & 308.25 & 220.00 & 1363.97 & 0.713 & \\
\hline $25 / 11$ & 24 & 202 & 238.40 & 204.00 & 1427.73 & 0.707 & \\
\hline 平 均 & & 214 & 298.83 & 212.90 & 1395.85 & 0.710 & \\
\hline $25 /$ II & \multicolumn{7}{|c|}{ 㙞 } \\
\hline $7 /$ III & 24 & 177 & 251.78 & 180.00 & 1422.52 & 0.714 & +1.9 \\
\hline $11 /$ iI & \multicolumn{7}{|c|}{ プロラン A. B. 汪射閏始 } \\
\hline $12 / \|$ & 24 & 190 & 280.52 & 210.00 & 1476.43 & 0.747 & +5.7 \\
\hline $17 /:$ & 24 & 198 & 289.60 & 212.00 & 1462.63 & 0.732 & +4.7 \\
\hline $22 / \prime \prime$ & 24 & 193 & 264.00 & 200.00 & 1367.87 & 0.757 & -2.0 \\
\hline $27 / / 1$ & 24 & 196 & 258.23 & 190.00 & 1317.51 & 0.735 & -5.6 \\
\hline $1 / I V$ & 24 & 191 & 281.25 & 210.00 & 1472.55 & 0.746 & +5.4 \\
\hline $6 / \|$ & 24 & 208 & 282.91 & 210.00 & 1360.14 & 0.742 & -2.6 \\
\hline \multicolumn{8}{|c|}{ 白 } \\
\hline $10 /$ III & 24 & 233 & 300.68 & 240.90 & 1290.48 & 0.798 & \\
\hline $12 / /$ & 24 & 218 & 272.46 & 220.00 & 1249.86 & 0.807 & \\
\hline 平 均 & & 226 & 286.57 & 230.00 & 1270.17 & 0.803 & \\
\hline $12 /$ III & \multicolumn{7}{|c|}{ 脾 } \\
\hline $22 / 11$ & 24 & 220 & 297.85 & 228.00 & 1353.90 & 0.765 & +6.5 \\
\hline $26 / \mathbb{I I}$ & \multicolumn{7}{|c|}{ プラロン A. B. 注射開始 } \\
\hline $27 / / 1$ & 24 & 234 & 301.41 & 236.00 & 1288.10 & 0.782 & +1.4 \\
\hline $1 / \mathrm{IV}$ & 24 & 238 & 311.89 & 248.00 & 1310.49 & 0.795 & +3.1 \\
\hline $6 / 1 /$ & 24 & 246 & 303.35 & 228.00 & 1233.13 & 0.751 & -2.9 \\
\hline $11 / "$ & 24 & 234 & 303.04 & 240.00 & 1295.05 & 0.791 & +1.9 \\
\hline $16 / / /$ & 24 & 243 & 296.69 & 232.00 & 1220.96 & 0.781 & -3.8 \\
\hline $21 / / 1$ & 24 & 227 & 277.72 & 212.00 & 1223.47 & 0.763 & -3.6 \\
\hline
\end{tabular}




\begin{tabular}{|c|c|c|c|c|c|c|c|}
\hline \multirow[b]{2}{*}{ 檢查日附 } & \multirow{2}{*}{$\begin{array}{l}\text { 絕 食 } \\
\text { 時 間 }\end{array}$} & \multirow[b]{2}{*}{$\begin{array}{c}\text { 體 重 } \\
\text { (瓦) }\end{array}$} & \multicolumn{3}{|c|}{$\begin{array}{c}\text { 互 斯 代 謝 } \\
\text { 每時 } 0^{\circ} \mathrm{C} 760 \mathrm{~mm} \mathrm{Hg}\end{array}$} & \multirow{2}{*}{$\begin{array}{l}\text { 呼 吸 } \\
\text { 係 數 }\end{array}$} & \multirow{2}{*}{ 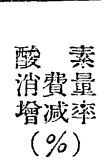 } \\
\hline & & & $\begin{array}{c}\text { 酸蒸消費量 } \\
\text { (䇇) }\end{array}$ & 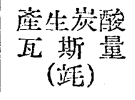 & 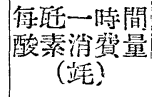 & & \\
\hline \multicolumn{8}{|c|}{ 白 } \\
\hline $12 /$ 近 & 24 & 214 & 291.45 & 224.00 & 1361.94 & 0.768 & \\
\hline $14 / "$ & 24 & 205 & 285.46 & 212.00 & 1392.53 & 0.742 & \\
\hline 平 均 & & 210 & 288.46 & 218.00 & 1377.24 & 0.755 & \\
\hline 14/II & \multicolumn{7}{|c|}{ 脾臟剔出 } \\
\hline $24 / 7$ & 24 & 201 & 264.99 & 200.00 & 1318.38 & 0.754 & -4.2 \\
\hline $28 /$ [II & \multicolumn{7}{|c|}{ プロランA.B. 汢射闒炲 } \\
\hline $29 / / 1$ & 24 & 220 & 281.87 & 220.00 & 1281.27 & 0.780 & -6.9 \\
\hline $3 / \mathrm{IV}$ & 24 & 202 & 277.74 & & 1374.95 & & -0.1 \\
\hline $8 / "$ & 24 & 202 & 300.82 & 240.00 & 1489.23 & 0.797 & +8.1 \\
\hline $13 / "$ & 24 & 199 & $2 £ 7.85$ & 196.00 & 1295.73 & 0.760 & -5.9 \\
\hline $18 / \|$ & 24 & 194 & 278.15 & 214.00 & 1433.78 & 0.769 & +4.1 \\
\hline $23 / 11$ & 24 & 187 & 243.67 & 192.00 & 1303.06 & 0.788 & -5.3 \\
\hline \multicolumn{8}{|c|}{ 白. } \\
\hline $12 / \pi$ & 24 & 196 & 246.71 & 184.00 & 1258.77 & 0.745 & \\
\hline $14 / / 1$ & 24 & 198 & 246.58 & 186.00 & 1245.29 & 0.754 & \\
\hline 本 均 & & 197 & 246.64 & 185.00 & 1252.03 & 0.750 & \\
\hline $14 / \mathbb{I I}$ & \multicolumn{7}{|c|}{ 聘臟 剔出 } \\
\hline $24 / " \prime$ & 24 & 185 & 234.64 & 174.00 & 1268.37 & 0.741 & +1.3 \\
\hline 28/II & \multicolumn{7}{|c|}{ プロラン A. B. 注射開始 } \\
\hline $29 / 11$ & 24 & 196 & 254.98 & 190.00 & 1300.92 & 0.745 & +3.9 \\
\hline $3 / I V$ & 24 & 200 & 24 b.25 & 188.00 & 1226.25 & 0.766 & -2.0 \\
\hline $8 / " 1$ & 24 & 200 & 266.02 & 212.00 & 1330.10 & 0.796 & +6.2 \\
\hline $13 / \prime \prime$ & 24 & 199 & 262.30 & 212.00 & 1318.11 & 0.808 & +5.2 \\
\hline $18 / 1 "$ & 24 & 188 & 230.26 & 178.00 & 1224.82 & 0.773 & -2.1 \\
\hline $23 / "$ & 24 & 186 & 233.10 & 182.00 & 1253.27 & 0.780 & +0.1 \\
\hline
\end{tabular}


籍三言第一群

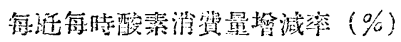

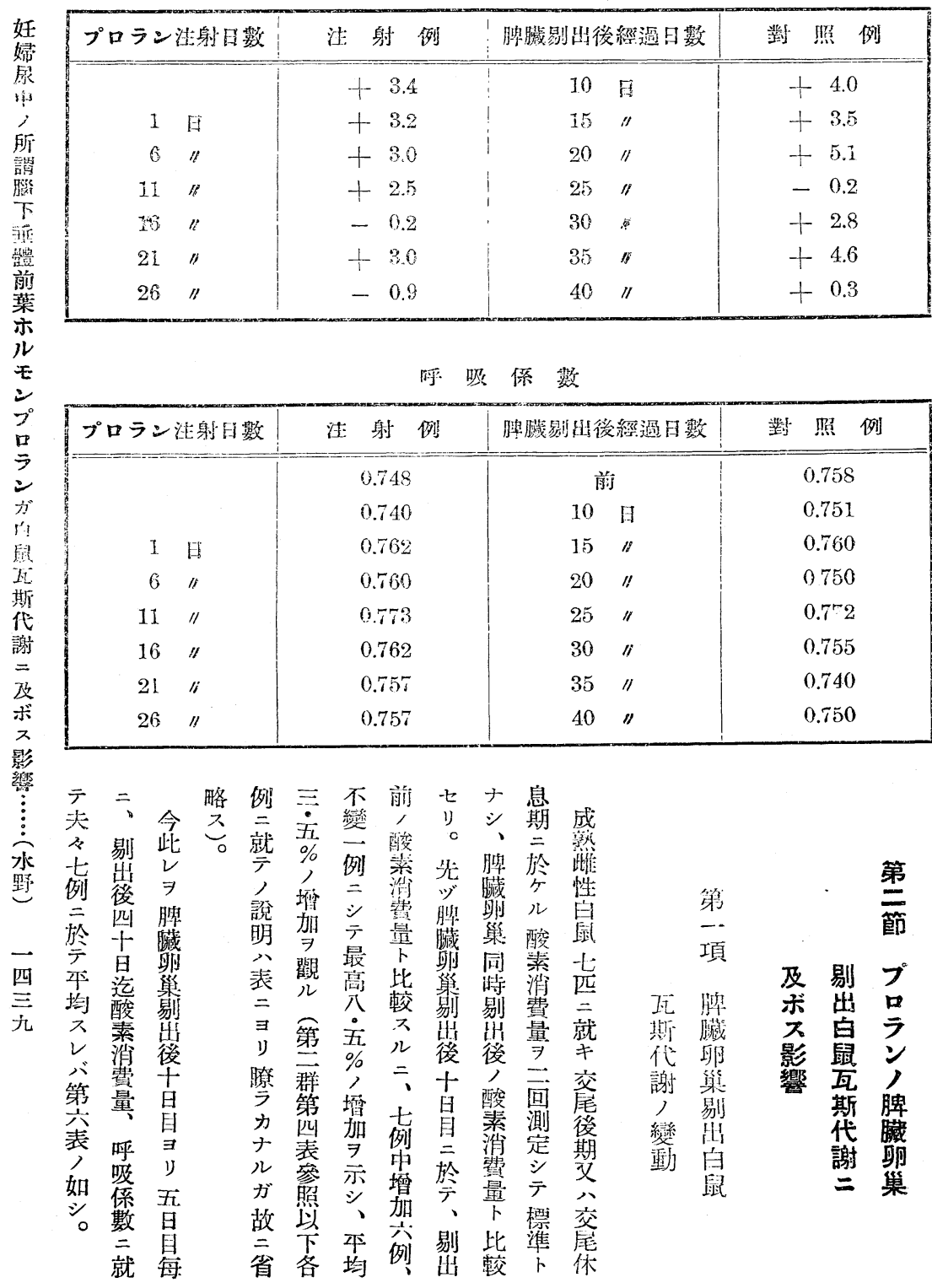


第 四表 第二 群

\begin{tabular}{|c|c|c|c|c|c|c|c|}
\hline \multirow[b]{2}{*}{ 檢查日附 } & \multirow{2}{*}{$\begin{array}{l}\text { 絕 食 } \\
\text { 時 間 }\end{array}$} & \multirow[b]{2}{*}{$\begin{array}{l}\text { 體 重 } \\
\text { (互) }\end{array}$} & \multicolumn{3}{|c|}{$\begin{array}{c}\text { 萹 斯 代 謝 } \\
\text { 每時 } 0^{\circ} \mathrm{C} 760 \mathrm{~mm} \mathrm{Hg}\end{array}$} & \multirow{2}{*}{$\begin{array}{l}\text { 呼 吸 } \\
\text { 係 數 }\end{array}$} & \multirow[b]{2}{*}{$\begin{array}{c}\text { 霓 素 } \\
\text { 消費量 } \\
\text { 增減率 } \\
(\%)\end{array}$} \\
\hline & & & $\begin{array}{c}\text { 酸素消費量 } \\
\text { (靖) }\end{array}$ & $\begin{array}{l}\text { 產生炭酸 } \\
\text { 斯 量 } \\
\text { (距) }\end{array}$ & $\begin{array}{c}\text { 每聒一時間 } \\
\text { 酸素渻蚛量 } \\
\text { (靖) }\end{array}$ & & \\
\hline \multicolumn{8}{|c|}{ 白 } \\
\hline $2 / \mathrm{VI}$ & 24 & 199 & 255.13 & 200.00 & 1282.07 & 0.783 & \\
\hline $7 / " 1$ & 24 & 203 & 256.19 & 188.00 & 1262.06 & 0.749 & \\
\hline 平均 & & 201 & 255.66 & 194.00 & 1272.07 & 0.766 & \\
\hline $9 / \mathrm{VI}$ & \multicolumn{7}{|c|}{ 脾臟並＝卵临剔出 } \\
\hline $19 / " \prime$ & 24 & 173 & 230.16 & 178.00 & 1330.44 & 0.773 & +4.5 \\
\hline $24 / V I$ & 24 & 181 & 240.08 & 180.00 & 1326.42 & 0.749 & $\dashv-4.2$ \\
\hline $29 / / /$ & 24 & 188 & 243.43 & 184.00 & 1294.85 & 0.755 & +1.8 \\
\hline $4 / \mathrm{VII}$ & 24 & 192 & 246.47 & 184.00 & 1283.69 & 0.746 & +0.9 \\
\hline $9 / " \prime$ & 24 & 203 & 227.34 & 172.00 & 1119.92 & 0.756 & -11.9 \\
\hline $14 / "$ & 24 & 202 & 234.38 & 176.00 & 1160.33 & 0.750 & -8.7 \\
\hline $19 / / /$ & 24 & 203 & 248.83 & 192.60 & 1225.76 & 0.771 & -3.6 \\
\hline \multicolumn{8}{|c|}{ 白 } \\
\hline $8 / \mathrm{VI}$ & 24 & 207 & 272.17 & 208.00 & 1314.85 & 0.764 & \\
\hline $10 / 11$ & 24 & 205 & 286.45 & 212.00 & 1397.34 & 0.740 & \\
\hline 平均 & & 206 & 279.31 & 210.00 & 1356.10 & 0.752 & \\
\hline $11 / \mathrm{VI}$ & \multicolumn{7}{|c|}{ 脾臟並 = 卵集剔出 } \\
\hline $21 / \|$ & 24 & 192 & 264.99 & 204.00 & 1380.20 & 0.769 & +1.7 \\
\hline $26 / V !$ & 24 & 203 & 278.14 & 220.00 & 1370.19 & 0.790 & +1.0 \\
\hline $1 /$ VII & 24 & 213 & 292.16 & 228.00 & 1371.66 & 0.780 & +1.1 \\
\hline $6 / 11$ & 24 & 216 & 286.64 & 216.00 & 1327.06 & 0.753 & -2.1 \\
\hline $1 \mathrm{I} / \mathrm{\prime}$ & 24 & 219 & 294.04 & 224.00 & 1342.66 & 0.761 & -0.9 \\
\hline $16 / / 1$ & 24 & 217 & 287.41 & 220.00 & 1324.47 & 0.765 & -2.3 \\
\hline $21 / \prime \prime$ & 24 & 219 & 289.24 & 220.00 & 1320.73 & 0.760 & -2.6 \\
\hline \multicolumn{8}{|c|}{ 白 } \\
\hline $18 / \mathrm{Vl}$ & 24 & 200 & 237.09 & 174.00 & 1185.45 & 0.733 & \\
\hline $20 / " \prime$ & 24 & 201 & 240.25 & 180.00 & 1195.31 & 0.749 & \\
\hline 平 均 & & 201 & 238.67 & 177.00 & 1190.38 & 0.741 & \\
\hline
\end{tabular}




\begin{tabular}{|c|c|c|c|c|c|c|c|}
\hline \multirow[b]{2}{*}{ 檢查日附 } & \multirow{2}{*}{$\begin{array}{ll}\text { 絕 食 } \\
\text { 時 間 }\end{array}$} & \multirow[b]{2}{*}{$\begin{array}{l}\text { 體 重 } \\
\text { (瓦) }\end{array}$} & \multicolumn{3}{|c|}{$\begin{array}{c}\text { 丽 斯 代 謝 } \\
\text { 每時 } 0^{\circ} \mathrm{C} 760 \mathrm{~mm} \mathrm{Hg}\end{array}$} & \multirow{2}{*}{$\begin{array}{l}\text { 呼 吸 } \\
\text { 保 數 }\end{array}$} & \multirow{2}{*}{$\begin{array}{c}\text { 酸素素消費量 } \\
\text { 增減率 } \\
(\%)\end{array}$} \\
\hline & & & \begin{tabular}{|c|} 
酸素消費量 \\
(站)
\end{tabular} & $\begin{array}{l}\text { 铂生炭酸 } \\
\text { 斯 量 } \\
\text { (竓) }\end{array}$ & $\begin{array}{c}\text { 每㥀一時間 } \\
\text { 酸素消費量 } \\
\text { (站) }\end{array}$ & & \\
\hline $21 / \mathrm{VI}$ & \multicolumn{7}{|c|}{ 脾歲並 = 卵巢剔出 } \\
\hline $1 / \mathrm{VI}$ & 24 & 170 & 214.94 & 160.00 & 1264.37 & 0.744 & $1+6.2$ \\
\hline $6 / \mathrm{VI}$ & 24 & 159 & 204.37 & 154.00 & 1285.38 & 0.753 & +7.9 \\
\hline $11 / 1 /$ & 24 & 165 & 204.12 & 150.00 & 1237.10 & 0.734 & +3.9 \\
\hline $16 / \|$ & 24 & 180 & 206.81 & 158.00 & 1148.97 & 0.763 & -3.4 \\
\hline $21 / \|$ & 24 & 185 & 203.12 & 144.00 & 1097.99 & 0.703 & -7.7 \\
\hline $26 / \prime \prime$ & 24 & 196 & 217.02 & 164.00 & 1107.24 & 0.755 & -6.9 \\
\hline $31 / \|$ & 24 & 196 & 220.32 & 160.00 & 1124.13 & 0.726 & -5.5 \\
\hline \multicolumn{8}{|c|}{ 白 } \\
\hline $15 / \mathrm{VI}$ & 24 & 211 & 258.75 & 192.00 & 1226.34 & 0.742 & \\
\hline $17 / \pi$ & 24 & 218 & $297: 51$ & 212.00 & 1364.75 & 0.712 & \\
\hline 平均 & & 215 & 278.13 & 202.00 & 1295.55 & 0.727 & - \\
\hline $21 / \mathrm{VI}$ & \multicolumn{7}{|c|}{ 脾臟並 = 卵巢剔出 } \\
\hline $1 / \mathrm{VII}$ & 24 & 154 & 216.51 & 172.00 & 1405.92 & 0.794 & +8.5 \\
\hline $6 / \mathrm{VI}$ & 24 & 160 & 210.65 & 162.00 & 1316.57 & 0.769 & +1.6 \\
\hline $11 / "$ & 24 & 172 & 220.93 & 166.00 & 1284.52 & 0.751 & -0.8 \\
\hline $16 / " \prime$ & 24 & 175 & 223.91 & 168.00 & 1279.31 & 0.750 & -1.2 \\
\hline $21 / / 1$ & 24 & 185 & 233.17 & 180.00 & 1260.40 & 0.771 & -2.7 \\
\hline $26 / " 1$ & 24 & 187 & 240.35 & 180.00 & 1285.34 & 0.748 & $\therefore 0.7$ \\
\hline $31 / \|$ & 24 & 192 & 247.71 & 184.00 & 1290.16 & 0.742 & -0.4 \\
\hline \multicolumn{8}{|c|}{ 白 } \\
\hline $3 / v \llbracket$ & 24 & 186 & 220.05 & 172.00 & 1183.07 & 0.781 & \\
\hline $5 / \|$ & 24 & 184 & 218.27 & 164.00 & 1186.25 & 0.751 & \\
\hline 平 均 & & 185 & 219.16 & 168.00 & 1184.66 & 0.766 & \\
\hline $7 / \mathrm{VI}$ & \multicolumn{7}{|c|}{ 胆臟並 = 卵巢剔出 } \\
\hline $17 / \prime \prime$ & 24 & 183 & 221.00 & 164.00 & 1207.65 & 0.742 & +1.9 \\
\hline
\end{tabular}




\begin{tabular}{|c|c|c|c|c|c|c|c|}
\hline \multirow[b]{2}{*}{ 檢查日附 } & \multirow{2}{*}{ 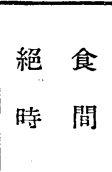 } & \multirow[b]{2}{*}{$\begin{array}{c}\text { 體 重 } \\
\text { (瓦) }\end{array}$} & \multicolumn{3}{|c|}{$\begin{array}{c}\text { 氐 斯 代 謝 } \\
\text { 年寺 } 0^{\circ} \mathrm{C} 760 \mathrm{~mm} \mathrm{Hg}\end{array}$} & \multirow{2}{*}{$\begin{array}{l}\text { 呼 吸 } \\
\text { 俰 數 }\end{array}$} & \multirow{2}{*}{$\begin{array}{c}\text { 酸素 } \\
\text { 消費量 } \\
\text { 增减獍 } \\
(\%)\end{array}$} \\
\hline & & & $\begin{array}{c}\text { 酸素消費量 } \\
\text { (站) }\end{array}$ & $\begin{array}{c}\text { 產生若酸 } \\
\text { 瓦斯量 } \\
\text { (洭) }\end{array}$ & $\begin{array}{c}\text { 每话一時間 } \\
\text { 酸表消留量 } \\
\text { (靖) }\end{array}$ & & \\
\hline $22 /$ VII & 24 & 184 & 231.54 & 172.00 & 1258.38 & 0.742 & +6.2 \\
\hline $27 / \prime \prime$ & 24 & 185 & 234.36 & 174.00 & 1266.84 & 0.742 & +6.9 \\
\hline $1 /$ VIII & 24 & 178 & 219.24 & 166.00 & 1231.73 & 0.757 & +3.9 \\
\hline $6 / 1 /$ & 24 & 192 & 238.92 & 180.00 & 1244.37 & 0.753 & +5.0 \\
\hline $11 / / /$ & 24 & 200 & 227.80 & 174.00 & 1139.04 & 0.763 & -3.8 \\
\hline $16 / \prime \prime$ & 24 & 211 & 243.49 & 188.00 & 1153.98 & 0.772 & -2.5 \\
\hline \multicolumn{8}{|c|}{ 白 } \\
\hline $5 / \mathrm{VI}$ & 24 & 229 & 319.48 & 228.00 & 1395.12 & 0.713 & \\
\hline $9 / \|$ & 24 & 223 & 290.06 & 224.00 & 1300.74 & 0.772 & \\
\hline 平 均 & & 226 & 304.77 & 226.00 & 1347.93 & 0.743 & \\
\hline $14 / \mathrm{VII}$ & \multicolumn{7}{|c|}{ 脾臟並 = 卵笨剔出 } \\
\hline $24 / I I$ & 24 & 218 & 299.79 & 220.00 & 1375.21 & 0.733 & +2.0 \\
\hline $29 /$ VII & 24 & 224 & 289.39 & 216.00 & 1291.93 & 0.746 & -4.1 \\
\hline $3 /$ VIII & 24 & 229 & 304.53 & 230.00 & 1329.83 & 0.755 & -1.3 \\
\hline $8 / 11$ & 24 & 212 & 291.33 & 220.00 & 1374.19 & 0.755 & +1.9 \\
\hline $13 / \prime \prime$ & 24 & 220 & 缺 & & & & \\
\hline $18 / \prime \prime$ & 24 & 233 & 316.43 & 240.00 & 1358.09 & 0.758 & +0.7 \\
\hline $23 / / 1$ & 24 & 234 & 314.34 & 248.00 & 1343.36 & 0.788 & -0.3 \\
\hline \multicolumn{8}{|c|}{ 白 } \\
\hline $13 / \mathrm{VII}$ & 24 & 257 & 291.64 & 220.00 & 1134.80 & 0.754 & \\
\hline $15 / 11$ & 24 & 263 & 308.53 & 230.00 & 1173.11 & 0.745 & \\
\hline 本 均 & & 260 & 300.09 & 225.00 & 1153.95 & 0.750 & \\
\hline $17 / \mathrm{VII}$ & \multicolumn{7}{|c|}{ 聘藏並 = 卵森剔出 } \\
\hline $27 / 11$ & 24 & 232 & 267.49 & 202.00 & 1153.00 & 0.755 & - \\
\hline $1 / \mathrm{VGI}$ & 24 & 228 & 259.41 & 196.00 & 1137.77 & 0.755 & -1.4 \\
\hline $6 / 11$ & 24 & 231 & 271.03 & 204.00 & 1173.32 & 0.752 & +1.6 \\
\hline $11 / 1 /$ & 24 & 230 & 255.56 & 190.00 & 1111.14 & 0.743 & -3.7 \\
\hline $16 / " \prime$ & 24 & 232 & 245.98 & 184.00 & 1060.29 & 0.748 & -8.1 \\
\hline $21 / 11$ & 24 & 232 & 244.95 & 176.00 & 1055.83 & 0.718 & -8.5 \\
\hline $26 / 11$ & 24 & $2: 2$ & 245.87 & 180.00 & 1083.15 & 0.732 & -6.1 \\
\hline
\end{tabular}




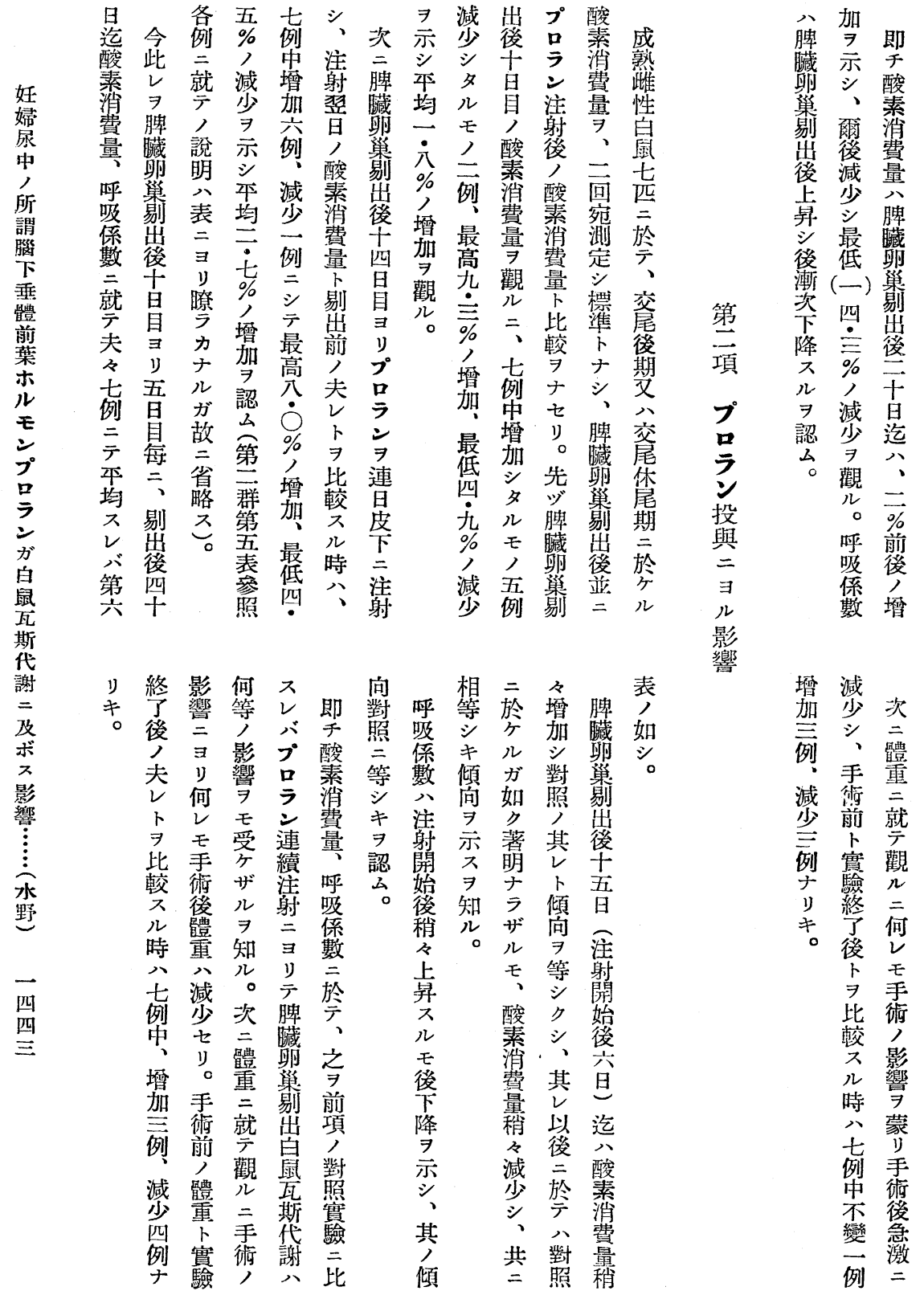


第五表 第二 群

\begin{tabular}{|c|c|c|c|c|c|c|c|}
\hline \multirow[b]{2}{*}{ 檢查日附 } & \multirow{2}{*}{$\begin{array}{l}\text { 絕 食 } \\
\text { 時 間 }\end{array}$} & \multirow[b]{2}{*}{$\begin{array}{l}\text { 體 重 } \\
\text { (桼) }\end{array}$} & \multicolumn{3}{|c|}{$\begin{array}{c}\text { 歪 斯 代 謝 } \\
\text { 每時 } 0^{\circ} \mathrm{C} 760 \mathrm{~mm} \mathrm{Hg}\end{array}$} & \multirow{2}{*}{$\begin{array}{l}\text { 呼 吸 } \\
\text { 俰 數 }\end{array}$} & \multirow[b]{2}{*}{$\begin{array}{c}\text { 酸素 } \\
\text { 消費量 } \\
\text { 增娍率 } \\
(\%) \\
(\%)\end{array}$} \\
\hline & & & $\begin{array}{c}\text { 酸素消費量 } \\
\text { (站) }\end{array}$ & $\begin{array}{l}\text { 產生炭酸 } \\
\text { 瓦 斯 量 } \\
\text { (竨) }\end{array}$ & $\left|\begin{array}{c}\text { 每䂡一時間 } \\
\text { 酸素消費量 } \\
\text { (站) }\end{array}\right|$ & & \\
\hline \multicolumn{8}{|c|}{ 白 } \\
\hline $28 / \mathrm{V}$ & 24 & 206 & 240.12 & 184.00 & 1165.64 & 0.766 & \\
\hline $1 / V I$ & 24 & 213 & 251.33 & 188.00 & 1179.99 & 0.748 & \\
\hline 平 均 & & 210 & 245.73 & 186.00 & 1172.81 & 0.757 & \\
\hline $4 / V I$ & \multicolumn{7}{|c|}{ 脾臟並 = 卵㫦剔出 } \\
\hline $14 / "$ & 24 & 211 & 245.31 & 188.00 & 1115.23 & 0.766 & -4.9 \\
\hline $18 / \mathrm{VI}$ & \multicolumn{7}{|c|}{ プロラン A. B. 注射開姶 } \\
\hline $19 / " /$ & 24 & 224 & 250.72 & 192.00 & 1119.31 & 0.765 & -4.5 \\
\hline $24 / \|$ & 24 & 224 & 251.78 & 190.00 & 1124.05 & 0.754 & -4.1 \\
\hline $29 / 1 /$ & 24 & 229 & 259.73 & 200.00 & 1134.21 & 0.770 & -3.2 \\
\hline $4 / \mathrm{VII}$ & 24 & 230 & 262.37 & 200.00 & 1140.76 & 0.762 & -2.7 \\
\hline $9 / \|$ & 24 & 234 & 269.57 & 204.00 & 1152.02 & 0.756 & -1.7 \\
\hline $14 / / \prime$ & 24 & 229 & 266.28 & 208.00 & 1162.81 & 0.781 & -0.8 \\
\hline \multicolumn{8}{|c|}{ 白 } \\
\hline $20 / V$ & 24 & 262 & 285.40 & 220.00 & 1089.32 & 0.770 & \\
\hline $5 / \mathrm{VI}$ & 24 & 271 & 290.12 & 220.00 & 1070.55 & 0.758 & \\
\hline 平均 & & 267 & 287.76 & 220.00 & 1079.94 & 0.764 & \\
\hline $8 / V I$ & \multicolumn{7}{|c|}{ 脾臟並 = 卵巢剔出 } \\
\hline $18 / \|$ & 24 & 231 & 263.13 & 200.00 & 1139.12 & 0.760 & +5.4 \\
\hline $22 / \mathrm{VI}$ & \multicolumn{7}{|c|}{ プロラン A. B. 注射開始 } \\
\hline $23 / 1 /$ & 24 & 247 & 281.99 & 214.00 & 1141.67 & 0.758 & +5.7 \\
\hline $28 / \|$ & 24 & 251 & 262.89 & 204.00 & 1047.39 & 0.775 & -3.0 \\
\hline $3 / V \square$ & 24 & 249 & 281.67 & 212.00 & 1131.23 & 0.752 & +4.7 \\
\hline $8 / 11$ & 24 & 252 & 286.01 & 218.00 & 1134.97 & 0.762 & +5.0 \\
\hline $13 / / 1$ & 24 & 253 & 278.30 & 210.00 & 1100.01 & 0.754 & +1.8 \\
\hline $18 / / 1$ & 24 & 236 & 268.62 & 204.00 & 1138.22 & 0.759 & +5.3 \\
\hline
\end{tabular}




\begin{tabular}{|c|c|c|c|c|c|c|c|}
\hline \multirow[b]{2}{*}{ 檢查日附 } & \multirow{2}{*}{$\begin{array}{ll}\text { 絕 } & \text { 食 } \\
\text { 時 間 }\end{array}$} & \multirow[b]{2}{*}{$\begin{array}{l}\text { 體 重 } \\
\text { （瓦） }\end{array}$} & \multicolumn{3}{|c|}{$\begin{array}{c}\text { 扁 斯 代 謝 } \\
\text { 每時 } 0^{\circ} \mathrm{C} 760 \mathrm{~mm} \mathrm{Hg}\end{array}$} & \multirow{2}{*}{$\begin{array}{l}\text { 呼 吸 } \\
\text { 係 數 }\end{array}$} & \multirow{2}{*}{$\begin{array}{l}\text { 酸素 } \\
\text { 消費量 } \\
\text { 增减率 } \\
(\%) \\
(\%)\end{array}$} \\
\hline & & & 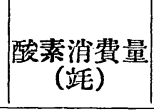 & $\begin{array}{c}\text { 竓生炭酸 } \\
\text { 篂 } \\
\text { (站) }\end{array}$ & $\begin{array}{c}\text { 每䏕一時間 } \\
\text { 酸素消費量 } \\
\text { (竨) }\end{array}$ & & \\
\hline \multicolumn{8}{|c|}{ 白 } \\
\hline $3 / \mathrm{VI}$ & 24 & 257 & 334.67 & 252.00 & 1302.24 & 0.752 & \\
\hline $6 / " 1$ & 24 & 256 & 343.78 & 260.00 & 1342.92 & 0,756 & \\
\hline 平 均 & & 257 & 339.23 & 256.00 & 1322.58 & 0.754 & \\
\hline $\begin{array}{l}11 / \mathrm{VI} \\
21 / \|\end{array}$ & \multicolumn{7}{|c|}{ 脾臟並 $=$ 卵巢剔出 } \\
\hline & \multirow{2}{*}{\multicolumn{7}{|c|}{ プロラ:- A. B. 注射開始 }} \\
\hline $25 / \mathrm{VI}$ & & & & & & & \\
\hline $26 / " /$ & 24 & 246 & 339.42 & 268.00 & 1339.11 & 0.789 & +1.2 \\
\hline $1 / \mathrm{VI}$ & 24 & 251 & 349.23 & 270.00 & 1391.38 & 0.773 & +5.2 \\
\hline $6 / 11$ & 24 & 261 & 346.84 & 276.00 & 1328.89 & 0.791 & +0.4 \\
\hline $11 / /$ & 24 & 263 & 336.17 & 264.00 & 1278.24 & 0.785 & -3.3 \\
\hline $16 / "$ & 24 & 267. & 355.71 & 270.00 & 1332.28 & 0.759 & \pm 0.7 \\
\hline $21 / 11$ & 24 & 279 & 366.82 & 278.00 & 1314.76 & 0.757 & $=0.5$ \\
\hline \multicolumn{8}{|c|}{ 白 } \\
\hline $14 / \mathrm{VI}$ & 24 & 196 & 219.31 & 166.00 & 1118.93 & 0.756 & \\
\hline $18 / / \prime$ & 24 & 204 & 227.66 & 170.00 & 1116.00 & 0.759 & \\
\hline 本均 & & 200 & 223.49 & 168.00 & 1117.46 & 0.758 & \\
\hline $21 / \mathrm{VI}$ & \multicolumn{7}{|c|}{ 脾臟並 = 卵巢剔出 } \\
\hline $1 / \mathrm{VII}$ & 24 & 177 & 201.27 & 156.00 & 1137.14 & 0.775 & +1.7 \\
\hline $5 / \mathrm{VII}$ & \multicolumn{7}{|c|}{ プロラン A. B. 注射開始 } \\
\hline $6 / 11$ & 24 & 191 & 223.10 & 176.00 & 1168.07 & 0.788 & +4.5 \\
\hline $11 / \|$ & 24 & 194 & 224.26 & 172.00 & 1155.97 & 0.766 & +3.3 \\
\hline $16 / 1 /$ & 24 & 190 & 216.66 & 168.00 & 1140.32 & 0.775 & +2.0 \\
\hline $21 / 1 /$ & 24 & 196 & 211.52 & 160.00 & 1079.19 & 0.756 & -3.4 \\
\hline $26 / 11$ & 24 & 203 & 232.32 & 174.00 & 1144.43 & 0.748 & +2.4 \\
\hline $31 / 1 /$ & 24 & 206 & 237.57 & 180.00 & 1153.29 & 0.757 & +3.2 \\
\hline
\end{tabular}




\begin{tabular}{|c|c|c|c|c|c|c|c|}
\hline \multirow[b]{2}{*}{ 检查日附 } & \multirow{2}{*}{$\begin{array}{l}\text { 絕食 } \\
\text { 時間 }\end{array}$} & \multirow[b]{2}{*}{$\begin{array}{c}\text { 體重 } \\
\text { (瓦) }\end{array}$} & \multicolumn{3}{|c|}{ 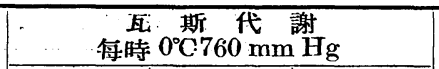 } & \multirow{2}{*}{$\begin{array}{l}\text { 呼吸 } \\
\cdots \cdots \\
\text { 保數 }\end{array}$} & \multirow{2}{*}{$\begin{array}{c}\text { 酸 素 } \\
\text { 消費 } \\
\text { 塄減率 } \\
(\%)\end{array}$} \\
\hline & & & $\left\{\begin{array}{c}\text { 酸素消費量 } \\
\text { (竜) }\end{array}\right.$ & $\begin{array}{l}\text { 產生炭酸 } \\
\text { 量 } \\
\text { (站) }\end{array}$ & $\begin{array}{c}\text { 每毦一時間 } \\
\text { 要素消費量 } \\
\text { (站) }\end{array}$ & & \\
\hline \multicolumn{8}{|c|}{12} \\
\hline $26 / \mathrm{VI}$ & 24 & 237 & 275.63 & 210.00 & 1163.03 & 0.761 & \\
\hline $29 / 1 /$ & 24 & 236 & 271.48 & 204.00 & 1150.34 & 0.751 & \\
\hline 平 均 & & 237 & 273.56 & 207.00 & 1156.68 & 0.756 & $\because$ \\
\hline $30 / \mathrm{VI}$ & \multicolumn{5}{|c|}{ 脾臟並 $=$ 卵黛剔出 } & & \\
\hline $10 / \mathrm{VII}$ & 24 & 214 & 255.60 & 196.00 & 1194.40 & 0.766 & +3.2 \\
\hline $14 / \mathrm{VII}$ & \multicolumn{7}{|c|}{ ブロランA. B. 注射開始 } \\
\hline $15 / \|$ & 24 & 227 & 267.97 & 200.00 & 1180.50 & 0.746 & +2.0 \\
\hline $20 / 11$ & 24 & 226 & 267.56 & 204.00 & 1183.91 & 0.762 & +2.3 \\
\hline $25 / 11$ & 24 & 221 & 257.14 & 194.00 & 1163.53 & 0.754 & +0.5 \\
\hline $30 / 11$ & 24 & 217 & 245.02 & 184.00 & 1129.16 & 0.750 & -2.3 \\
\hline $4 /$ VII & 24 & 213 & 247.75 & 184.00 & 1163.17 & 0.742 & +0.5 \\
\hline $9 / 1 /$ & 24 & 210 & 241.53 & 184.00 & 1150.14 & 0.761 & -0.5 \\
\hline \multicolumn{8}{|c|}{ 白 } \\
\hline $8 / V \pi$ & 24 & 253 & 278.32 & 208.00 & 1100.09 & 0.747 & \\
\hline $13 / " \prime$ & 24 & 247 & 290.17 & 224.00 & 1174.78 & 0.771 & \\
\hline 平 均 & & 250 & 284.25 & 216.00 & 1137.43 & 0.759 & \\
\hline $14 / \mathrm{VII}$ & \multicolumn{7}{|c|}{ 脾臟並 = 卵巢剔出 } \\
\hline $24 / \prime \prime$ & 24 & 225 & 250.12 & 188.00 & 1111.66 & 0.751 & -2.2 \\
\hline $28 / \mathrm{VI}$ & \multicolumn{7}{|c|}{ プロラン A. B 注射開始 } \\
\hline $29 / 11$ & 24 & 214 & 248.69 & 184.00 & 1162.14 & 0.747 & +2.1 \\
\hline $3 /$ VIII & 24 & 213 & 239.03 & 184.00 & 1122.20 & 0.769 & -1.3 \\
\hline $8 / "$ & 24 & 207 & 233.07 & 176.00 & 1125.97 & 0.755 & $-\ddot{1.0}$ \\
\hline $13 / "$ & 24 & 197 & & & & & \\
\hline $18 / "$ & 24 & 201 & 240.33 & 184.00 & 1195.71 & 0.765 & +5.1 \\
\hline $23 / \| \prime$ & 24 & 187 & 211.40 & 158.00 & $1130 \dot{.49}$ & 0.747 & -0.5 \\
\hline
\end{tabular}




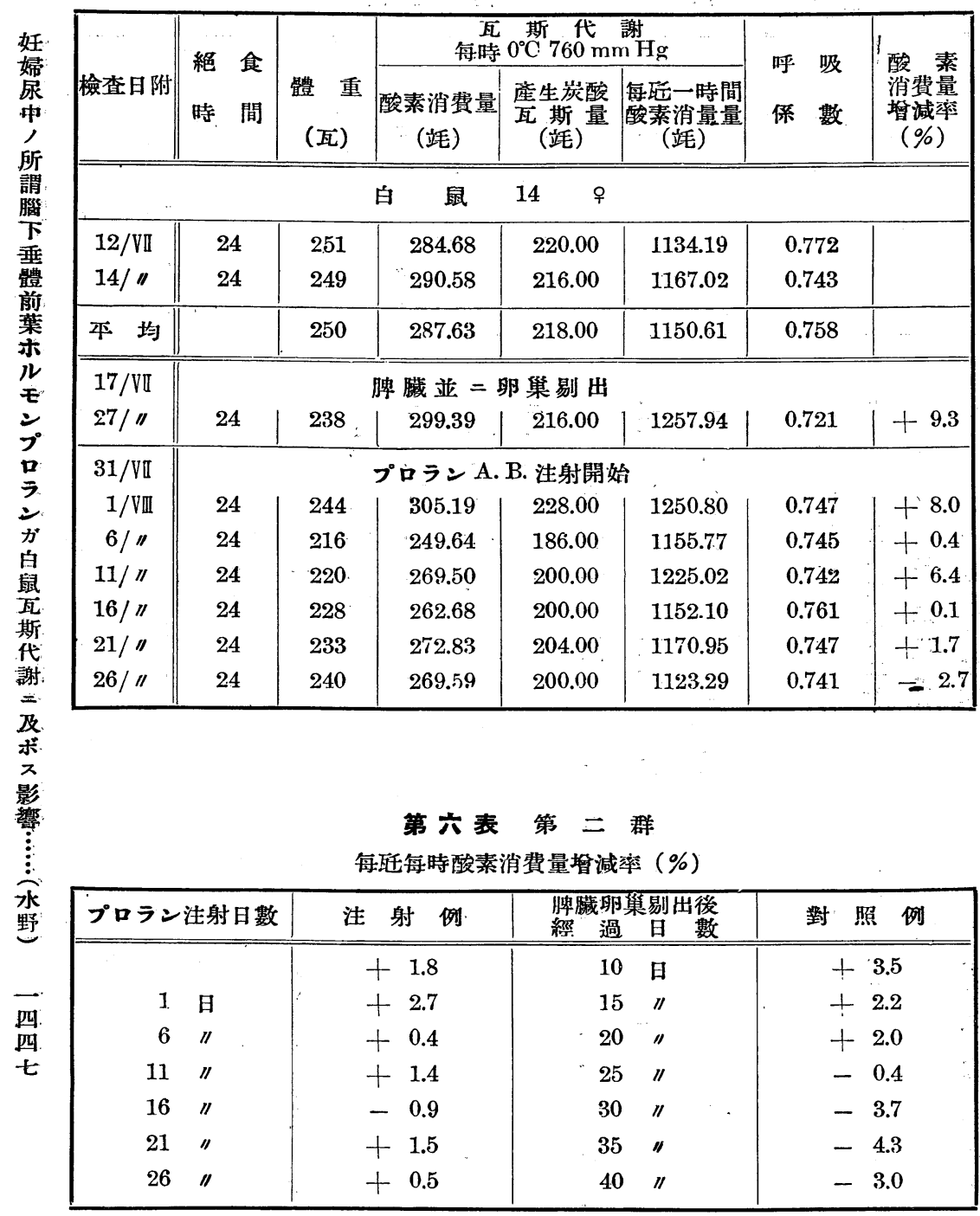


呼 吸 保 數

\begin{tabular}{|c|c|c|c|}
\hline プロラン注射日數 & 注 射 例 & $\begin{array}{l}\text { 脾臓卵笨剔出後 } \\
\text { 經 } \\
\end{array}$ & 對 照 例 \\
\hline & 0758 & 前 & 0.750 \\
\hline & 0.757 & 10 日 & 0.759 \\
\hline 1 日 & 0.763 & $15 \pi$ & 0.758 \\
\hline 611 & 0.763 & $20 " I$ & 0.753 \\
\hline 111 & 0.763 & $25 \quad \prime$ & 0.752 \\
\hline $16 / 1$ & 0.763 & $30 "$ & 0.750 \\
\hline $21 / 1$ & 0.753 & 35 & 0.751 \\
\hline 2611 & 0.757 & 4011 & 0.756 \\
\hline
\end{tabular}

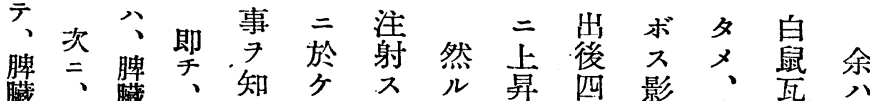

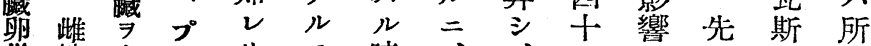

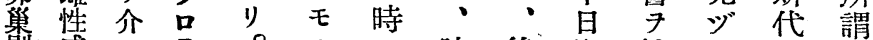

剔成吉ラ

出熟テ方、藏皆心索照三手

鼠鼠次 中全白剔降、浿及垂

瓦二的含 ク鼠出ス輕夕驗ボ體

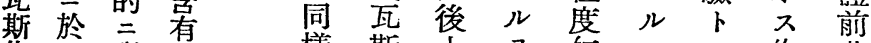

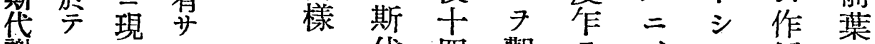

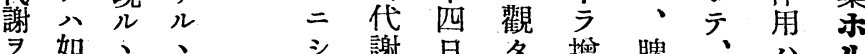

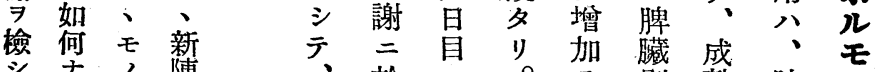

タナノ陳

ル 結 ル 謝

剔果 事 關

出 得 知 物

後儿筫

十 $\rightarrow$ 得

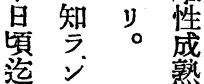

酸欲兒

湦

㸺告斯

プ 於

口酸、續後性

亏素 每

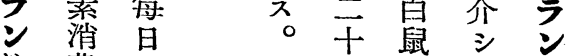

注費一呼 日 二テ 中

射量回吸頃於現二

二及—係汽染含

ヨビ定數分脾、有

リ呼量分酸藏モサ

何及剔素剔ノル

等 係 プ 出消出ナ、

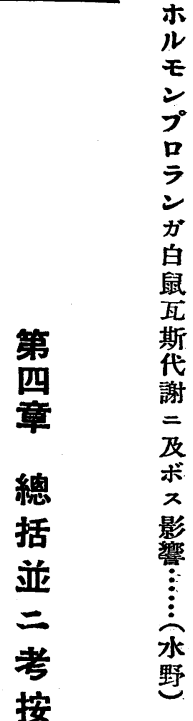

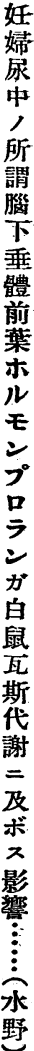

對尊

加照交

$=$

) 數

後費, リ新

影ノ 三 量白ヤ陳

響變 $ン$ 增 鼠否代

動 $\ni$ 五加瓦ヤ謝

モ

シ實紊對 下

頃、代 確 與

爾 $\stackrel{5}{5}$ 作

ス ケ照二

ザ䔈 連

迄爾謝 $x$ 物

輕 後二ン質

度剔及ガノ

$\overrightarrow{\text { 四 }}$
四 


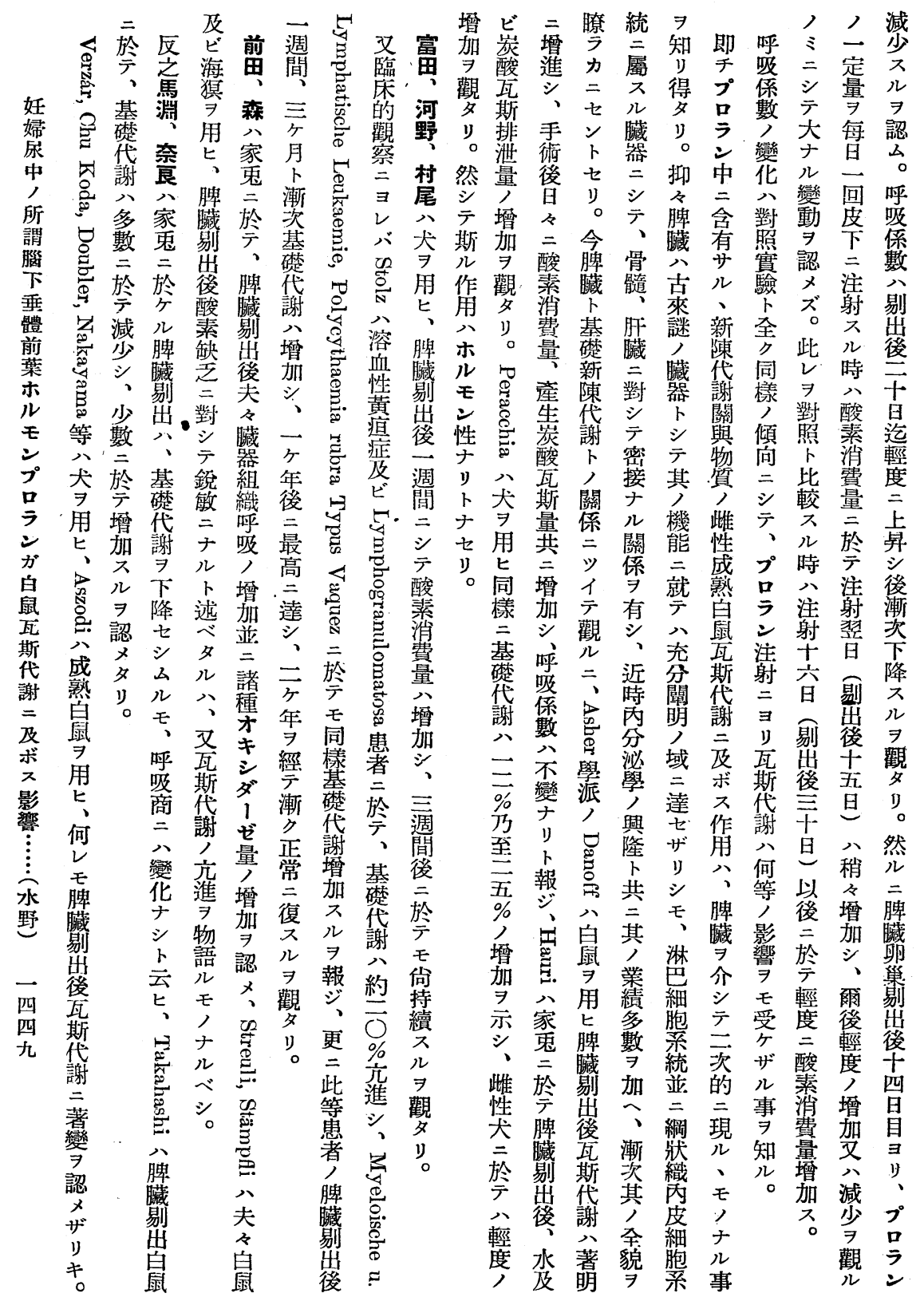




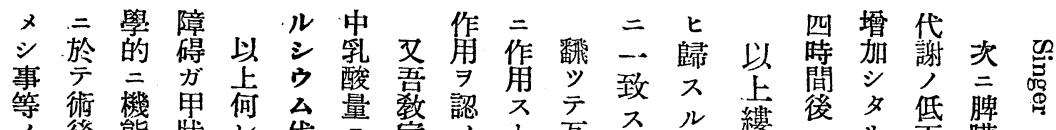

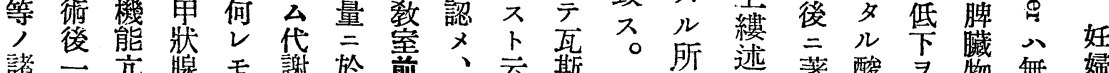

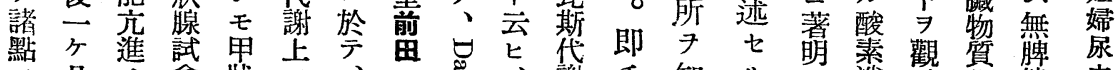

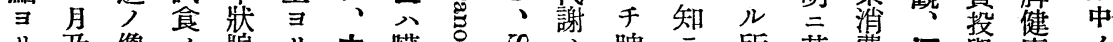

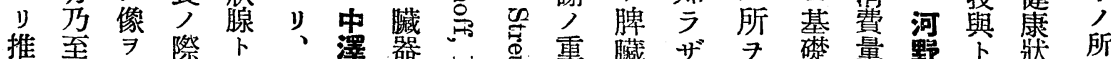

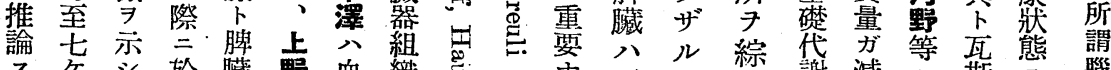

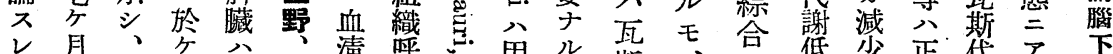

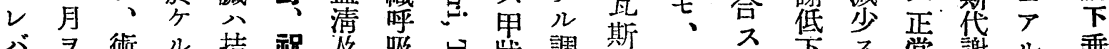

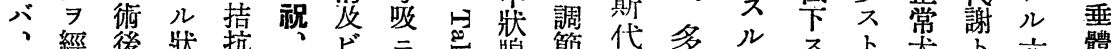

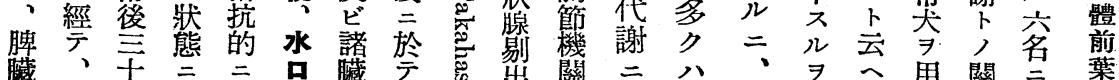

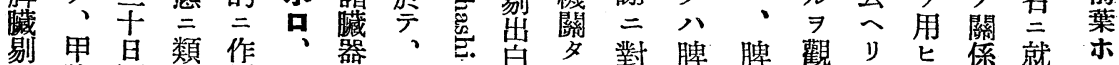

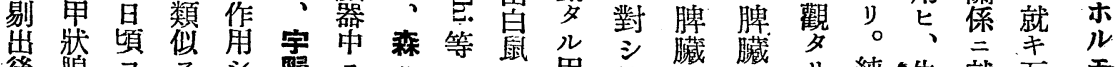
後腺 $\exists$ 、

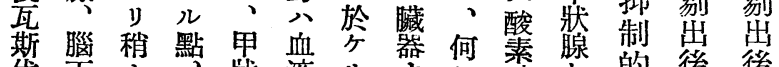

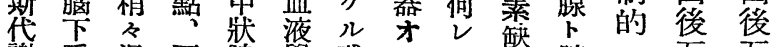

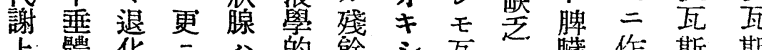

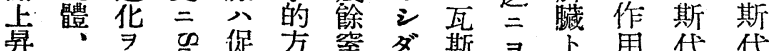

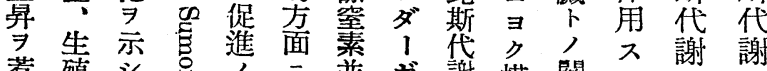

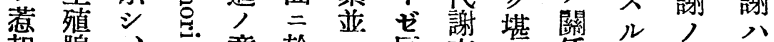

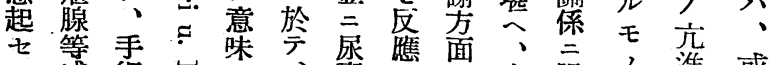

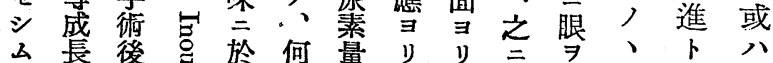
几發四岕示

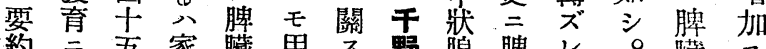
約三五家臟甸野腺脾々。藏 シ 密昱 鷄

テ 接 乃 剔關六七意臟り宮, 年出

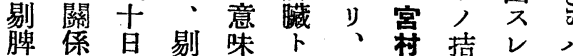
$=\exists=$ 脾三人新公抗

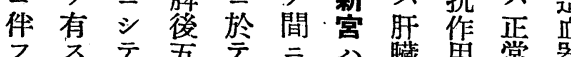

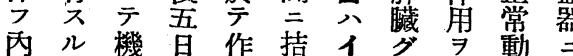

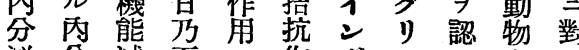

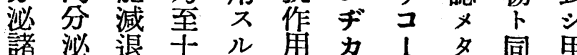

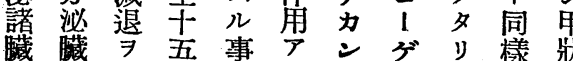

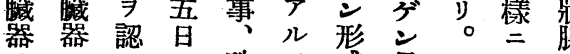
變 組、シ

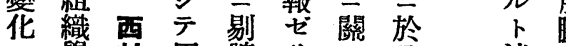

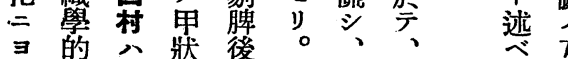

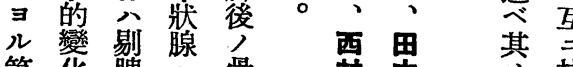

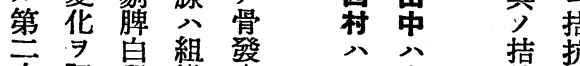

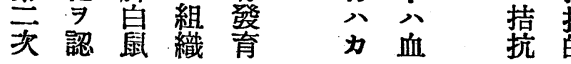

投與

後或 八

低 減

下 少

r

認 云

×

余又

成 著

績 變

モ

亦

此

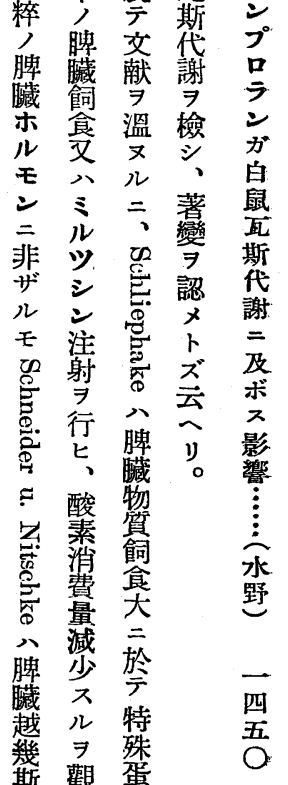


熟

白 余

鼠

妊 = 妊

婦 投 婦

尿 與 尿

中 シ

人 テり

所瓦 得

腦斯 夕

下代

垂 謝 所

體 キ 謂

前檢 腦

葉 シ下

ホ次垂

ルノ體

モ 如 前

プキ葉

口結 禾

ラ 猃

ン 調 モ

ガ得 ン

白 得

鼠多フ

斯

代

謝

政

ม

影

通

熟

野雄

西泉

五並

=

脾

臟

卵

画

同

時

剔

出

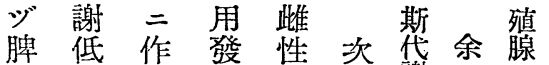

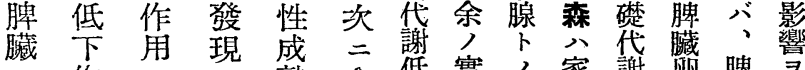
二作 ス ス 熟余低惯閿家謝留脾

作用ルル白八下驗間象八巢藏否

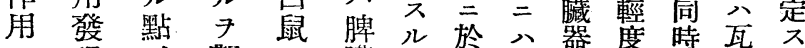
シ 現、・觀二臟事等、第三剔斯

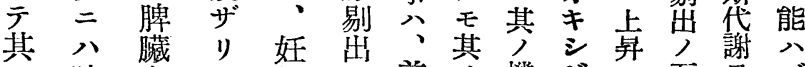

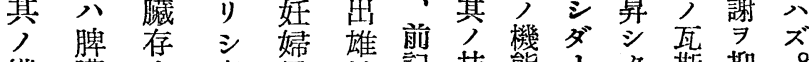

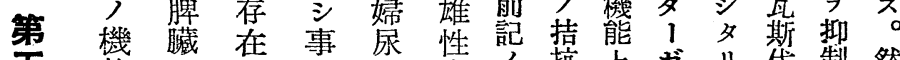

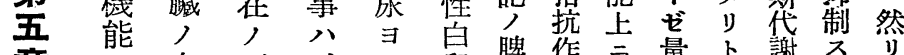
章 $チ$ 存下、、リ鼠藏㤰於量報謝

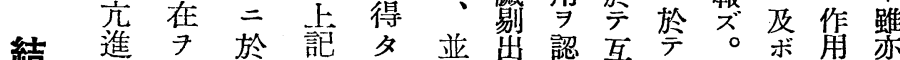

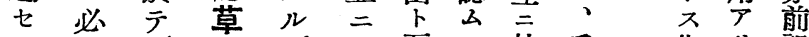

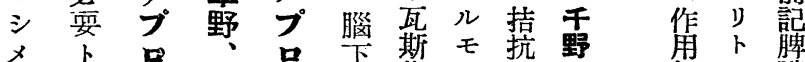

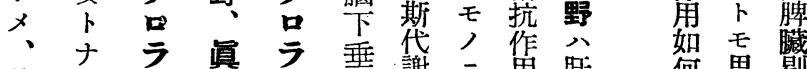

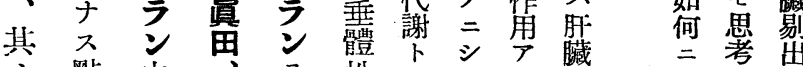
論了點中、 結 等二小注性關、トリリ热ル物 果 7 含 川射熟莉脾云コ 公べ基 三綜有, シ 禾並贜へ1 徵ク楚

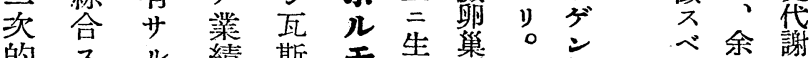

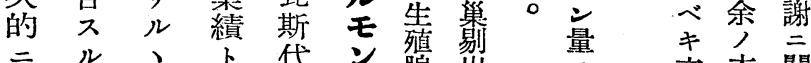

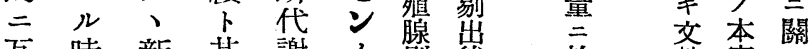
瓦時新其謝, 騡蛒於萳實

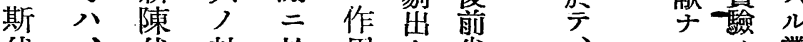
代: 代軌於用圣、尘業

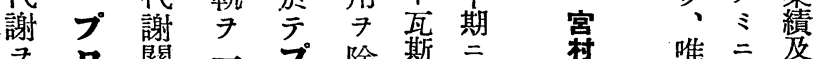

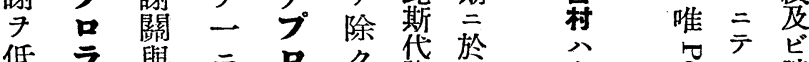
低 ラ 與 ニ

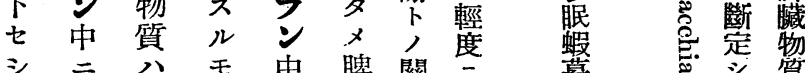

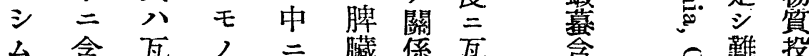

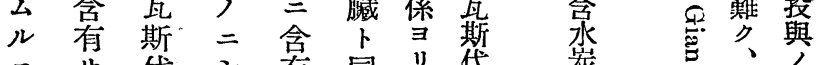
二サ代シ有同留帒

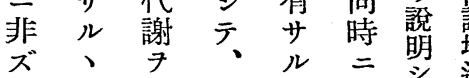
$ヤ$ 新低脾、卵得连

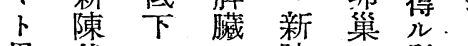
思帒七唯陳 7 所後於 惟謝 シ 瓦代モ车 ス關メ斯謝併 当期 物此謝與剔些 質 云物出輕 八宜 抑 質 シ 斯 麓 先代的作少酉

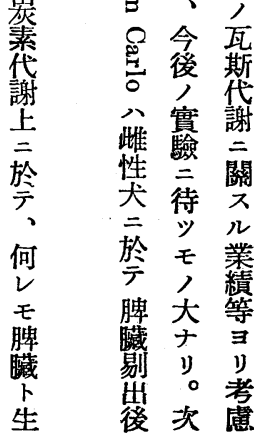




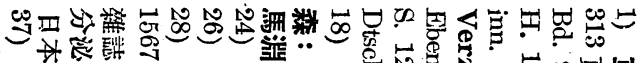

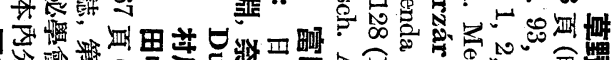

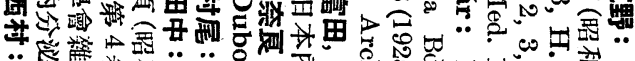

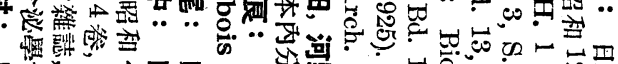

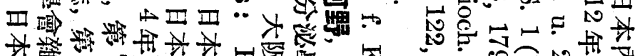

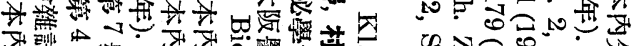

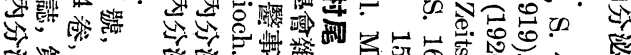

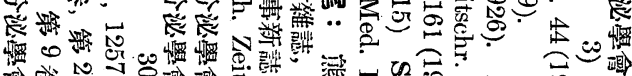

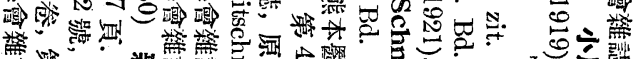

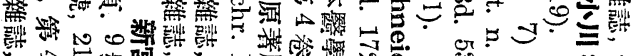

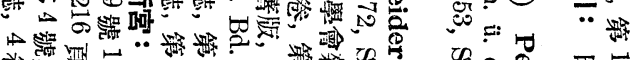
d.

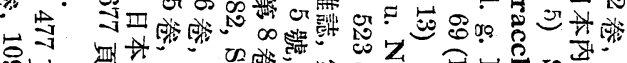

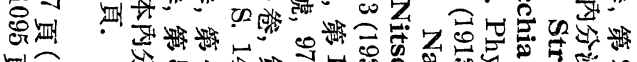

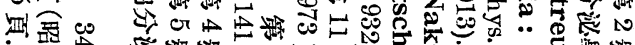

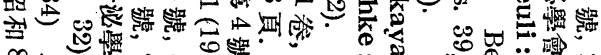

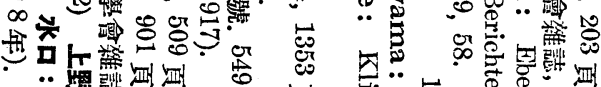

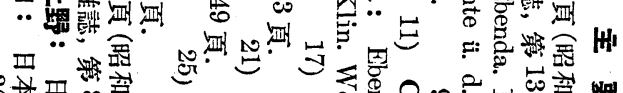

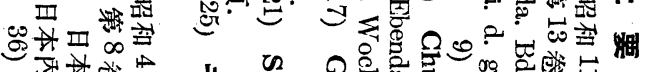

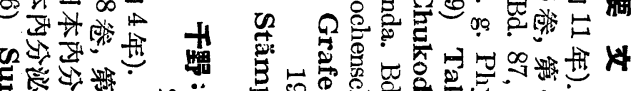

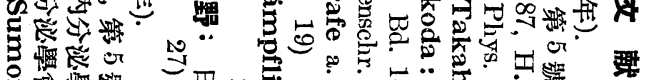

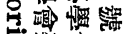

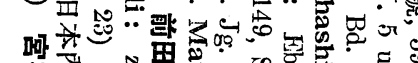

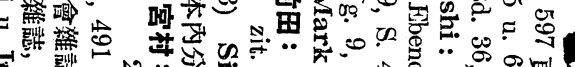

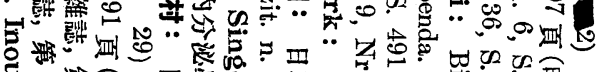

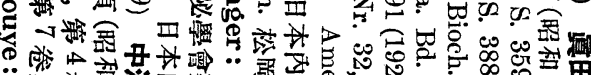

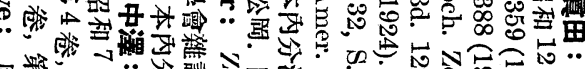

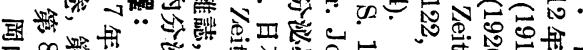

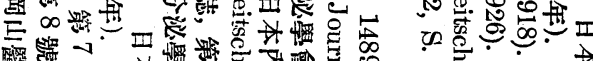

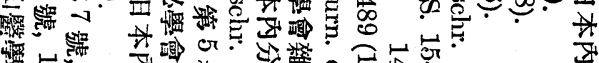

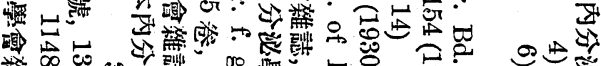

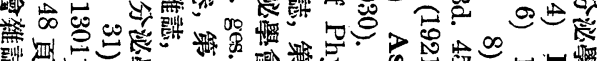

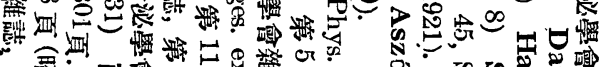

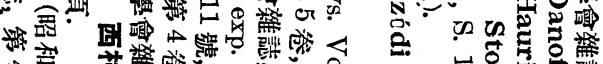

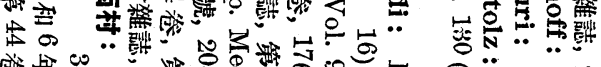

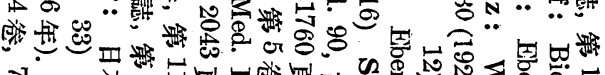

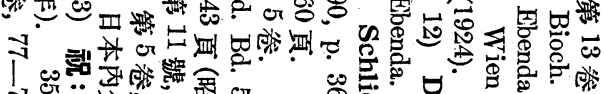
向

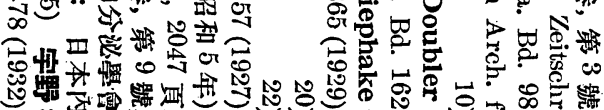

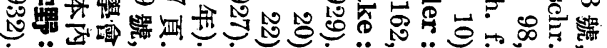

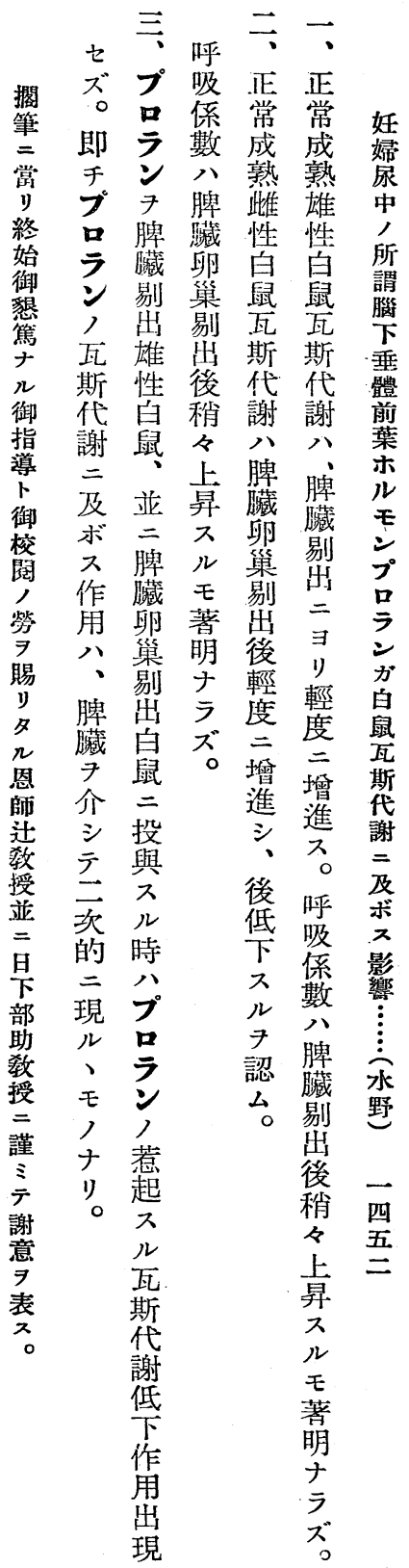




\title{
Über den Einfluss des Prolans auf die Gewebsatmung.
}

\author{
Von
}

Dr. Y. Schibata.

(Aus der I. Med. Klinik der Kaiserl. Universität zu Kyoto in Japan Direktor : Prof. Dr. K. Tsuji.)

Der Verfasser untersuchte den Einfluss des Prolans auf die Gewebsatmung in Schilddrüse, Leber, Milz und Niere. Als Versuchstiere wurden erwachsene männliche Ratten gebraucht.

Die Resultate waren wie folgt:

Bei wiederholter Injektion von Prolan (täglich einmal 10 Tage lang) fand sich der Sauerstoffverbrauch in der Schilddrüse ziemlich deutlich vermehrt, in der Leber dagegen leichtgradig vermindert, in der Milz leichtgradig und in Niere ziemlicn deutlich vermehrt.

(Autoreferat.)

\section{Studien über den Einfluss des Prolans auf den Gaswechsel. \\ V. Mitteilung. Versuche an splenektomierten männlichen Ratten sowie splenektomiert- ovariotomierten Ratten.}

Von

Dr. M. Mizuno.

(Aus der I. Med. Klinik der Kaiserl. Univers. zu Kyoto in Japan Direktor : Prof. Dr. K. Tsuji.)

Die Versuchsanordnungen waren wie in der 1. Mitteilung und die Resultate wie folgt:

1) Die Milzexstirpation steigerte bei der gesunden männlichen 
Ratte den Gaswechsel. Der R. Q. war nach der Milzexstirpation leicht gesteigert, jedoch nicht deutlieh.

2) Durch die gleichzeitige Exstirpation des Ovariums und der Milz nahm der Gaswechsel zunächst vorübergehend und darauf dauernd zu. Der R. Q. zeigte nach derselben Operation leichtgradigen Anstieg.

3) Die gaswechselerniedrigende Wirkung des Prolans manifestierte sich bei den splenektomierten männlichen Ratten sowie bei den splenektomiert-ovariotomierten Ratten nicht.

Aus dem Obigen darf man schliessen, dass es für die gaswechselbeeinflussende Wirkung des Prolans der Milz bedarf.

(Autoreferat)

\section{Untersuchungen über die Beziehung der ultravioletten Strahlen zu dem Knochenwachstum und den endokrinen Drüsen, besonders zur Thymusdrüse und $\mathrm{zu}$ den Geschlechtsdrüsen.}

I. Mitteilung. Morphologische Untersuchung.

Von

Dr. M. Iwakiri.

Aus der Abteilung für medizinische liadiologie u. physikalische Therapie der med. Fakultät Kumamoto, Japan (Direktor: A. O. Prof. Dr. K. Kameta).

Obgleich es nicht wenige Referate über die Untersuchung des: Verhältnisses zwischen der Thymusdrüse und dem Konchenwachstum sowie über das zwischen der Thymusdrüse sowie den Geschlechtsdrüsen und dem Konchenwachstum, wie z. B. die verschiedenen Arbeiten von Friedleben, Klose u. Vogt, Basch, Fischl, Tongu, Kiyonari, Katsura ete gibt, findet sich leider noch keine Literatur über die systematische Untersuchung des Verhältnisses der obenerwähnten endokrinen Drüsen zu den ultravioletten Strahlen, die doch beim Knochenwachstum eine so wichtige Rolle spielen. 